Rev. Int. Contam. Ambie. 37, 67-88, 2021

https://doi.org/10.20937/RICA.54066

\title{
A STUDY OF PM2.5 ELEMENTAL COMPOSITION IN SOUTHWEST MEXICO CITY AND DEVELOPMENT OF RECEPTOR MODELS WITH POSITIVE MATRIX FACTORIZATION
}

Estudio de la composición elemental de $\mathrm{PM}_{2.5}$ en el suroeste de la Ciudad de México y desarrollo de modelos de receptor con factorización de matriz positiva

\begin{abstract}
Alfonso Enrique HERNÁNDEZ-LÓPEZ ${ }^{1}$, Javier MIRANDA MARTÍN DEL CAMPO ${ }^{1 *}$, Violeta MUGICA ÁLVAREZ ${ }^{2}$, Brenda Liz VALLE-HERNÁNDEZ ${ }^{2}$, Lourdes Verónica MEJIA-PONCE ${ }^{1}$, Juan Carlos PINEDA-SANTAMARÍA ${ }^{1}$, Salvador REYNOSO-CRUCES ${ }^{1}$, Juan Antonio MENDOZA-FLORES ${ }^{1}$ and Daniel ROZANES-VALENZUELA ${ }^{3}$
\end{abstract}

${ }^{1}$ Departamento de Física Nuclear y Aplicaciones de la Radiación, Instituto de Física, Universidad Nacional Autónoma de México. Circuito Investigación Científica S/N, Ciudad Universitaria, Coyoacán, 04510, Ciudad de México, Mexico

${ }^{2}$ Universidad Autónoma Metropolitana-Azcapotzalco. Av. San Pablo 180, Col. Reynosa-Tamaulipas, Azcapotzalco, 02200, Ciudad de México, Mexico

${ }^{3}$ Red Universitaria de Observatorios Atmosféricos, Centro de Ciencias de la Atmósfera, Universidad Nacional Autónoma de México. Circuito Investigación Científica s/n, Ciudad Universitaria, Coyoacán, 04510, Ciudad de México, Mexico

*Author for correspondence: miranda@fisica.unam.mx

(Received: July 2020; accepted: October 2020)

Key words: $\mathrm{PM}_{2.5}$, elemental analysis, Mexico City, X-ray fluorescence, PMF.

\begin{abstract}
A study of elemental composition of $\mathrm{PM}_{2.5}$ samples collected at the main campus of the Universidad Nacional Autónoma de México, comprising data from 2015, 2016, and 2019, is described. X-ray fluorescence analysis was employed to measure concentrations of up to 19 elements, complemented with ion chromatography for eight ionic species (for samples of 2015 and 2016), and thermo-optical analysis for organic and elemental carbon (for samples of 2015). Positive matrix factorization (PMF) was applied to develop receptor models for each year, to identify polluting sources and their contributions to total mass. Five sources were identified in every case. With the aid of PMF, the influence of biomass burning on a major episode in May, 2019, was recognized. Comparisons with previous studies in this or nearby sites are also presented. It should be noted that only limited compositional data in this site are available since 2005 for the aerosol fine fraction.
\end{abstract}

Palabras clave: $\mathrm{PM}_{2.5}$, análisis elemental, Ciudad de México, fluorescencia de rayos X, PMF.

\section{RESUMEN}

Se presenta un estudio acerca de la composición elemental de muestras de $\mathrm{PM}_{2.5}$ en el campus principal de la Universidad Nacional Autónoma de México, incluyendo datos de 2015, 2016 y 2019. Se utilizó fluorescencia de rayos X para medir las concentraciones 
de hasta 19 elementos, complementando con cromatografía de iones para ocho especies (en muestras de 2015 y 2016), así como análisis termo óptico para carbono orgánico y elemental (en las muestras de 2015). El método de factorización de matriz positiva (PMF, por sus siglas en inglés) se aplicó para desarrollar modelos de receptor para cada año, con el fin de identificar fuentes contaminantes y sus contribuciones a la masa total. Se identificaron cinco fuentes en todos los casos. Con la ayuda de la PMF se comprobó la influencia de la quema de biomasa en un episodio durante mayo de 2019. También se presentan comparaciones con estudios previos en el sitio de interés u otros puntos cercanos. Se debe resaltar que a partir de 2005 sólo hay datos limitados acerca de la composición de la fracción fina del aerosol atmosférico.

\section{INTRODUCTION}

In the past decades, the air quality in the Mexico City Metropolitan Area (MCMA) has been the subject of continuous interest, not only for local scientists, but also for the international community (Molina et al. 2010). Airborne particulate matter (or PM) is especially important among the numerous pollutants (Vega et al. 2010), due to its possible biological effects (Osornio-Vargas et al. 2003), related to public health (Santibáñez-Andrade et al. 2020). Thus, it is essential to determine PM physical features, such as size or optical properties (Carabalí et al. 2019), as well as its chemical composition, including the presence of organic compounds (Amador-Muñoz et al. 2011), organic and elemental carbon (Vega et al. 1997), ionic species (Edgerton et al. 1999), or elemental concentrations (Landsberger and Creatchman 1999).

PM health effects are strongly influenced by its size. Particles with aerodynamic diameters below $10 \mu \mathrm{m}\left(\mathrm{PM}_{10}\right)$ and those smaller than $2.5 \mu \mathrm{m}\left(\mathrm{PM}_{2.5}\right)$ may affect human health, as they can be inhaled. Specifically, the latter can enter the deep respiratory tract and reach the alveoli, with a high probability of causing several diseases (Ibinarriaga-Montiel et al. 2019, Téllez-Rojo et al. 2020).

Due to the relevance of elemental analysis of PM at the MCMA, numerous studies have been performed since the first half of the 1980s. Several methods have been used to analyze the elemental composition of particulate matter, either as total suspended particles (TSP) or the respirable fractions $\mathrm{PM}_{10}$ and $\mathrm{PM}_{2.5}$. An example is X-ray spectrometry (Barfoot et al. 1984, Miranda et al. 1992, Miranda et al. 1994, Aldape and Flores 2004), extended with multivariate statistical analyses such as principal component analysis (PCA) (Thurston and Spengler 1985, Maenhaut and Cafmeyer 1987) or chemical mass balance (CMB) (Watson 1990). There are several illustrative study cases at the southwest MCMA (1993 to 2002) (Miranda et al. 1996, Paredes et al.1997, Miranda et al. 1998, Miranda et al. 2000, Miranda et al. 2004, Miranda et al. 2005), and others with data about organic carbon (OC), elemental carbon (EC), ionic species and elemental contents with X-ray fluorescence (XRF) (Chow et al. 2002, Vega et al. 2004, Vega et al. 2011).

The most widely known effort to characterize the pollutants, their origin, its transport and public health effects at the MCMA was the MILAGRO (Megacity Initiative: Local And Global Research Observations) campaign, carried out in March 2006 (Molina et al. 2010). As a result, in several papers, the chemical or elemental composition of PM, biological effects and optical properties were studied (Johnson et al. 2006, Moreno et al. 2008, Querol et al. 2008, Aiken et al. 2009, Mugica et al. 2009, Quintana et al. 2011, Peralta et al. 2019).

In contrast, other works present elemental concentration data, using nuclear activation analysis (Martínez 2000) or scanning electron microscopy with X-ray spectroscopy (Martínez et al. 2008). Moya et al. (2003) gave an analysis with ion chromatography of size-differentiated samples. Inductively coupled plasma mass spectrometry (ICP-MS) was employed to analyze samples collected in 2011 and 2013, to measure contents of ultra-trace elements, such as $\mathrm{Hg}$ (Morton-Bermea et al. 2018a) and Pt (MortonBermea et al. 2014, Garza-Galindo et al. 2020), as well as other geogenic metals (Morton-Bermea et al. 2018b, Garza-Galindo et al. 2019). Méndez-García et al. (2017) registered the presence of Th and U also with ICP-MS. Additionally, personal exposures to $\mathrm{PM}_{2.5}$ in 2002 were estimated from regression models applied to land use (Hinojosa-Baliño et al. 2019). Therefore, respirable particulate matter in the southwest MCMA is still an issue of great interest.

Since the development of MILAGRO campaign in 2006, several important conditions have changed 
at the MCMA. According to data from the United Nations Organization (UNO 2018), the population in the urban area grew from 19.27 million inhabitants in 2005 to an estimated 21.78 million in 2020 (a $13 \%$ increase). Moreover, the local emissions inventory points out that $\mathrm{PM}_{2.5}$ annual discharges to the MCMA atmosphere changed from $5499 \mathrm{t}$ in 2008 (SEDEMA 2010), to $15433 \mathrm{t}$ in 2016 (SEDEMA 2018); this represents a $180 \%$ growth. Although the southwest area in the MCMA has been the focus of the cited studies, it was not studied extensively during MILAGRO. Moreover, the existing information about $\mathrm{PM}_{2.5}$ elemental composition has been very limited in this area for more than ten years. Nonetheless, the Universidad Nacional Autónoma de México (UNAM) main campus is nowadays the center of extensive atmospheric studies, including air pollution (Peralta et al. 2016). But the population of this campus has also reflected the growth of the MCMA, with an estimated academic and student population of 119120 in 2005, to 176480 in 2019, which is an increase of $48 \%$ (UNAM 2019). An important intensification of local vehicular traffic, might also be expected. Although motor vehicle circulation data inside the campus are not available, the INEGI (2019) published a report indicating that officially registered vehicles in Mexico City grew from 2.7 million in 2005 to 5.8 million in 2018 (INEGI 2019). Therefore, the air pollution status, and especially the concentration and composition of airborne particulate matter, may have changed since 2006 to present days. As no systematic studies of $\mathrm{PM}_{2.5}$ elemental composition at the southwest region in the urban area have been carried out since 2004, it is necessary to continue with characterization of this fraction at the MCMA.

Bearing in mind all the above reasons, this work presents results about the elemental concentrations determined in $\mathrm{PM}_{2.5}$ samples collected in the UNAM main campus (southwest Mexico City), during campaigns carried out in the dry seasons of the years 2015, 2016, and 2019. Contents of elements $\mathrm{Na}$, $\mathrm{Mg}, \mathrm{Al}, \mathrm{Si}, \mathrm{P}, \mathrm{S}, \mathrm{Cl}, \mathrm{K}, \mathrm{Ca}, \mathrm{Ti}, \mathrm{V}, \mathrm{Cr}, \mathrm{Mn}, \mathrm{Fe}, \mathrm{Ni}$, $\mathrm{Cu}, \mathrm{Zn}, \mathrm{Se}$, and $\mathrm{Pb}$ were determined with $\mathrm{XRF}$, in 2015 complemented with organic carbon (OC) and elemental carbon (EC), as well as several ionic species by ion chromatography (IC), in 2015 and 2016. Enrichment factors (EF), were employed to identify elements with possible geogenic emitting sources. PMF was applied to all the data sets to identify the contributing sources. Comparisons with previous studies of $\mathrm{PM}_{2.5}$ composition in this area are presented, to assess the development of this fraction along the aforementioned time period. Additionally, the 2019 campaign allows contrasting morning versus afternoon sampling periods.

\section{MATERIALS AND METHODS}

\section{Sampling periods and procedures}

$\mathrm{PM}_{2.5}$ samples were collected during three different campaigns carried out in 2015, 2016 and 2019. Filters for 2015 and 2016 campaigns were exposed at the rooftop of the Centro de Ciencias de la Atmósfera, UNAM, main building (latitude $19^{\circ} 19^{\prime} 31^{\prime \prime} \mathrm{N}$, longitude $99^{\circ} 10^{\prime} 51^{\prime} \mathrm{W}$, altitude $2280 \mathrm{~m}$ a.s.l). Samples for 2019 were collected at the rooftop of the Colisiones building, Instituto de Física, UNAM (latitude $19^{\circ} 19^{\prime} 27^{\prime}$ ' N, longitude $99^{\circ} 10^{\prime} 37^{\prime \prime} \mathrm{W}$, altitude $2280 \mathrm{~m}$ a.s.1.). Both sites are inside the UNAM main campus at a distance of $225 \mathrm{~m}$. The study area has a more residential type, with lower population density than other areas on the MCMA, and is surrounded by green spaces. The main emission sources in the area are private vehicles and public transport. Finally, the sites are located in the Coyoacán County, which has $76.7 \%$ of its territory classified as tree-covered. The location of the site is schematized in figure $\mathbf{1}$, together with places where other studies have been carried out.

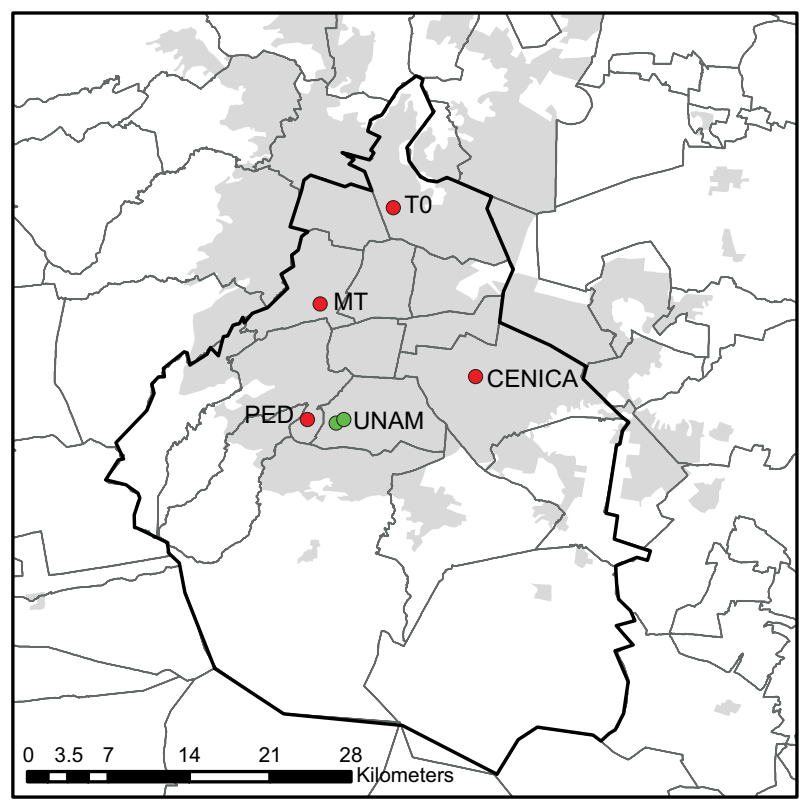

Fig. 1. Map of Mexico City showing the site of study (CCA) and other places where similar studies have been carried out: T0 (Querol et al. 2008), CENICA (Salcedo et al. 2006), PED (Vega et al. 2004) and MT (Miranda et al. 1992, Miranda et al. 1994). The shaded region represents the limits of the urban area. 
The details of the 2015 campaign are thoroughly described by Salcedo et al. (2018). The samples were collected during dry-winter season, from January 16 to March 26, 2015, daily from 8:00 h to 7:00 h of the next day (23 h), including weekends, during the whole campaign. Two low volume samplers (MiniVol TAS, Airmetrics, OR, USA) operating at $5.0 \mathrm{~L} / \mathrm{min}$, with a type $\mathrm{B}$ uncertainty of $0.5 \mathrm{~L} / \mathrm{min}$, were employed to acquire a total of 126 samples (two for each campaign date). The 2016 sampling was carried out during the dry-warm season, from March 1 to June 7, 2016. Integrated $24 \mathrm{~h}$ samples were collected (12:00 am to 12:00 am) every two days using the same low volume sampler as above. A total of 60 samples were accumulated. Finally, for the last year, the filters were collected in two periods: from 7:00 $\mathrm{h}$ to 13:00 $\mathrm{h}$ and 13:30 $\mathrm{h}$ to $19: 30 \mathrm{~h}$., from March 19 to May 31, 2019 (dry-warm season), from Monday to Saturday of each week, avoiding holidays, due to limited access to the sampling site. The employed device was an Ecotech AAS 271 Mini (Ecotech Instruments, Kasna, India), which operated at a flux of $16.67(0.67) \mathrm{L} / \mathrm{min}$ for $\mathrm{PM}_{2.5}$ collection. There was a total of 89 valid samples for 2019. All the samplers have calibration certificates. Moreover, comparisons between the operation of MiniVol and Ecotech samplers have been presented by ReynosoCruces (2020) and Mejía-Ponce (2020), showing a very good agreement between both devices.

For each year, different types of filters were employed. During 2015, samples were collected on polycarbonate membrane filters (SPI, USA, $47 \mathrm{~mm}$, $0.4 \mu \mathrm{m}$ pore size) and quartz filters (Pall Corp., USA, $47 \mathrm{~mm}, 0.3 \mu \mathrm{m}$ pore size). Polycarbonate filters were conditioned in room with controlled humidity $(\mathrm{RH}<$ $30 \%)$ and temperature $\left(25^{\circ} \mathrm{C}\right)$ for at least $48 \mathrm{~h}$ prior to sampling. These filters were used for gravimetric determination of $\mathrm{PM}_{2.5}$ mass concentration by weighting before and after airborne particles collection, using an electronic microbalance (BA2105, Sartorius, Germany) with a resolution of $0.01 \mathrm{mg}$, whereas quartz filters were pre-combusted at $600{ }^{\circ} \mathrm{C}$ for $5 \mathrm{~h}$ and then stored in the controlled room with the same conditions mentioned above. In addition, during the 2016 period, only polycarbonate filters were used, for the XRF elemental and ion chromatography (IC) analyses; the same filter pre-conditioning procedure as in 2015 was followed. Finally, during the 2019 sampling, Teflon ${ }^{\circledR}$ filters were utilized (Teflon ${ }^{\circledR}$ type, Pall Corp., $47 \mathrm{~mm}$, $1 \mu \mathrm{m}$ pore size), also under the same preconditioning as the polycarbonate filters; this material was preferred due to the higher air flux in the sampler, to assure proper particle retention. However, in 2016 and 2019 an Ohaus 200GD electrobalance (0.01 mg resolution) was employed for the gravimetric mass determinations. OC and EC were measured only in 2015, and ionic species in 2015 and 2016. Moreover, due to unavailable sampling devices in 2017 and 2018, the next campaign was performed until 2019.

\section{Meteorological data}

Data for wind speed and velocity were obtained from the Red Automática de Monitoreo Atmosférico (RAMA, for its acronym in Spanish) official site (SEDEMA 2020a), during the three campaigns. In addition, three-dimensional winds were measured by the Lidar Leosphere Windcube profiler, located at the CCA site of the Red Universitaria de Observatorios Atmosféricos de la Universidad Nacional Autónoma de México, RUOA-UNAM (Peralta et al. 2016).

\section{Chemical analyses}

The organic carbon and elemental carbon concentrations in the $\mathrm{PM}_{2.5}$ samples were determined at the Universidad Autónoma Metropolitana, Azcapotzalco, using a carbon analyzer (Sunset Laboratory Model-4, Tigard, OR, USA) with thermal-optical transmittance (TOT), and laser-based pyrolysis correction and compatibility with the accepted $\mathrm{Na}-$ tional Institute for Occupational Safety and Health (NIOSH) protocol (Birch and Cary 1996). A piece with an approximated area of $1 \mathrm{~cm}^{2}$ was cut from a quartz filter sample and placed in the oven. The oven was heated up to $870{ }^{\circ} \mathrm{C}$ in a helium atmosphere to desorb the organic compounds and the pyrolysis products from the sample and convert them to carbon dioxide $\left(\mathrm{CO}_{2}\right)$ using manganese dioxide $\left(\mathrm{MnO}_{2}\right)$ in an oxidation oven. Finally, the $\mathrm{CO}_{2}$ was detected and quantified by a self-contained non-dispersive infrared system (NDIR). Subsequently, the sample oven was cooled at $600{ }^{\circ} \mathrm{C}$ and reheated to a final temperature of $870{ }^{\circ} \mathrm{C}$ in a helium-oxygen $\left(\mathrm{He}-\mathrm{O}_{2}\right)$ atmosphere for the oxidation of elemental carbon. This $\mathrm{CO}_{2}$ corresponding to $\mathrm{EC}$ was detected by NDIR system. Also, methane was used as external standard for the calculation of OC and EC concentrations. All samples were analyzed by duplicate, quality control assurance was made by analyzing blank samples and the combined uncertainty for each sample was calculated as the square root of the sum of the covariance for the duplicates and the variability of the system, according to the procedure described by the Joint Committee for Guides in Metrology (JCGM 2008). The limits of detection for these analyses were $0.10 \mu \mathrm{g} / \mathrm{m}^{3}$ for EC and $0.11 \mu \mathrm{g} / \mathrm{m}^{3}$ for OC, evaluated through the procedure explained by Miller and Miller (2018). 
Elemental concentrations in the $\mathrm{PM}_{2.5}$ were analyzed with a custom-built XRF spectrometer for environmental applications (Espinosa et al. 2012). It is equipped with an Oxford Instruments (Mountain View, CA, USA) X-ray tube with $\mathrm{Rh}$ anode operated at $50 \mathrm{keV}$ and $500 \mu \mathrm{A}$, while the detection system consisted in an Amptek (Bedford, MA, USA) Si-PIN $\mathrm{X}$-ray detector with resolution of $160 \mathrm{eV}$ at $5.9 \mathrm{keV}$, for the 2015 samples, and an Amptek X-123SDD spectrometer to analyze the 2016 and 2019 sets, with a resolution of $120 \mathrm{eV}$ at $5.9 \mathrm{keV}$. The filters were placed in the analysis chamber at high vacuum $\left(10^{-6}\right.$ torr) and an XRF spectrum was collected for $900 \mathrm{~s}$ and subsequently integrated with the Quantitative Xray Analysis System (QXAS) (IAEA 2007). Blanks were subtracted from sample concentrations. X-ray self-attenuation corrections were applied for the lightest elements ( $\mathrm{Na}, \mathrm{Mg}, \mathrm{Al}, \mathrm{Si}$ ), based on XCOM mass attenuation coefficients (Saloman et al. 1988). Replicate analyses were performed with all samples and combined uncertainties were calculated for each sample as reported by Espinosa et al. (2010). These uncertainties ranged between $5 \%$ for major elements and $15 \%$ for the less abundant ones. As expressed by the JCGM (2008), the uncertainty of a measurement reflects the lack of exact knowledge of the value of the measurand. Also, Maenhaut (2004) showed that uncertainties below $20 \%$ are acceptable for PIXE analyses of $\mathrm{Al}$ in aerosol samples, so the same can be expected for the present data. For these reasons, with these uncertainties the results obtained can be considered reliable estimations of the elemental concentrations.

The calibration procedure of the XRF spectrometer was carried out using thin film standards (MicroMatter Co., Vancouver, Canada) irradiated during 300 $\mathrm{s}$ under the same conditions as the sample analysis. Afterwards, accuracy verifications have been carried out using the NIST standard reference material 2783, Air Particulate on Filter Media (Mejía-Ponce et al. 2018).

Furthermore, ionic contents of $\mathrm{PM}_{2.5}$ samples were determined by high performance liquid chromatography (HPLC), according to the procedure described by Sosa-Echeverría, et al. (2019). Sample treatment was made following the methods for ultrasound assisted extraction reported in other studies (Saldarriaga-Noreña et al. 2014, Espinosa et al. 2019). Briefly, the sample was placed in a low-density polyethylene (LDPE) container with $20 \mathrm{~mL}$ of type I laboratory water (ultra-pure, Milli-Q, Merck, Germany) and extracted in an ultrasonic bath at $40 \mathrm{kHz}$ (Witeg WUC-D22H, Wertheim, Germany), for one hour at $60^{\circ} \mathrm{C}$. Subsequently, a second extraction with $20 \mathrm{~mL}$ of new solvent was followed. The volume collected was adjusted to $50 \mathrm{~mL}$, and filtered using Teflon ${ }^{\circledR}$ filters with a pore diameter of $0.25 \mu \mathrm{m}$ and confined in LDPE containers for further analysis. Cations were analyzed without chemical suppression in a Waters equipment (MA, USA) with an added column for IC-Pak cations (Waters, MA, USA) and a conductivity detector. Potassium carbonate (6.0 $\mathrm{mM}$ ) was used as the mobile phase at a flow rate of $0.8 \mathrm{~mL} / \mathrm{min}$; the injection volume was $10 \mu \mathrm{L}$. Anions were analyzed with chemical suppression, in a Perkin Elmer HPLC (MA, USA) equipped with a Hamilton PRPX-100 anion column and a conductivity detector. A solution of sodium carbonate and bicarbonate (8.0:4.0 $\mathrm{mM})$ was used as mobile phase, at a flow rate of $0.7 \mathrm{~mL} / \mathrm{min}$. Injection volume was $10 \mu \mathrm{L}$. Instrumental calibration curves for all species were constructed in a range between $0.1 \mathrm{mg} / \mathrm{L}$ and 10 $\mathrm{mg} / \mathrm{L}$. Correlation coefficients, precision and limits of detection for instrumental analytical method along with recovery tests for the ion extraction method are summarized in Supplementary material, section S3.

\section{RESULTS AND DISCUSSION}

\section{Analytical quality verification}

In order to assess the gravimetric mass data quality, figure 2 displays the $\mathrm{PM}_{2.5}$ mass measured in the filters and those reported by the RAMA (UNAM station) in 2019 (SEDEMA 2020a). The high

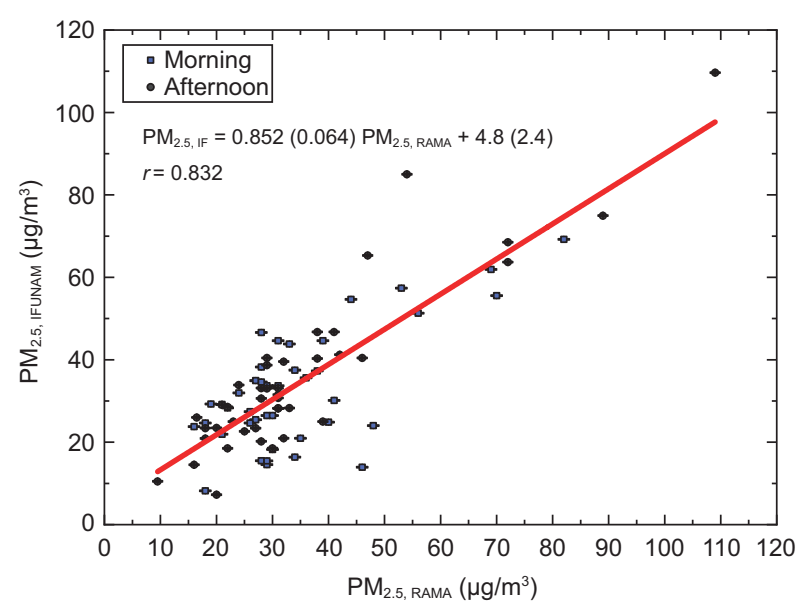

Fig. 2. $\mathrm{PM}_{2.5}$ mass concentrations measured during the 2019 sampling period as a function of the concentration determined by the RAMA (SEDEMA 2019), at the UNAM station. Morning and afternoon samples are differentiated. 
Pearson correlation coefficient $(r=0.832)$ and the slope of the fitted line $(0.852$ (0.064)) demonstrate that the mass concentrations measured during the 2019 sampling are accurate, taking the RAMA values as a reference. As explained by Taylor (1997), this correlation is highly significant, because, considering the number of experimental points, the probability that both variables are not correlated is less than 1 $\%$. Moreover, when the slope of the adjusted line is close to 1, as in the present case, both measurement results are very similar.

The explanation of accuracy verification of the XRF analyses of NIST Standard Reference Material 2783 can be found in Section S1 of the Supplementary material. Based on this, the forthcoming results of concentration determinations in the $\mathrm{PM}_{2.5}$ elemental analyses can be considered as reliable, with care for $\mathrm{Mg}, \mathrm{Al}, \mathrm{Mn}$, and $\mathrm{Zn}$. Additionally, limits of detection (LOD) for a Teflon ${ }^{\circledR}$ filter loaded with $\mathrm{PM}_{2.5}$ are displayed in figure $\mathbf{S 2}$, determined under the same X-ray fluorescence experimental conditions as the reference material; thus, it is expected to have similar detection limits for the targets. These LOD are calculated on the basis of background radiation, and is proportional to the square root of the number of counts in the background below the analyzed X-ray peak (Kadachi and Al-Eshaikh 2012). This number is given in the report of the analysis of each spectrum with QXAS (IAEA 2007).

Moreover, figure 3 illustrates the agreement between XRF and IC procedures, where ion $\mathrm{SO}_{4}{ }^{2-}$ and elemental S results during the 2016 campaign are

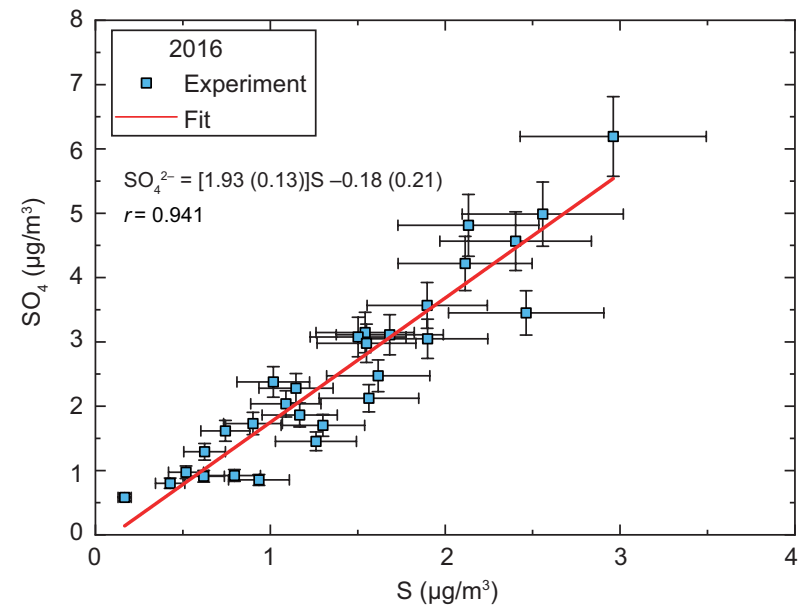

Fig. 3. Comparison of $\mathrm{S}(\mathrm{XRF})$ and $\mathrm{SO}_{4}{ }^{+}$(IC) concentrations determined during the 2016 campaign. The agreement is very good, although an excess of $\mathrm{S}$ in the particles is observed, not included in the sulfate ion. presented; the slope of the fitted line is $1.93(0.13)$. The ratio of the molecular mass $(\mathrm{MM})$ of the ion $\mathrm{SO}_{4}{ }^{2-}(\mathrm{MM}=96)$ to elemental $\mathrm{S}(\mathrm{MM}=32)$ is 3 . $\mathrm{XRF}$ determines only total elemental $\mathrm{S}$ concentrations. So, if all the elemental sulfur was due to $\mathrm{SO}_{4}{ }^{2-}$, the expected slope would be equal to 3 . However, the slope is 1.93 , a value considerably less than 3 , meaning that there is more sulfur in the samples than the amount contained in the $\mathrm{SO}_{4}{ }^{2-}$ ion. It should be noted that there are other sources of $\mathrm{S}$ in the aerosols reported in previous works, like $\mathrm{SO}_{2}$ and other minor derived compounds (Saxena and Seigneur 1989, Ye et al. 2014). In the case of the 2015 data, there is an excellent agreement with the expected slope when $\mathrm{S}$ is present as sulfate ion in $\mathrm{PM}_{2.5}$, which is 3 , with an experimental slope of $3.05(0.23)$.

\section{Chemical analyses results}

$\mathrm{XRF}$ analyses gave results for 15 elements in 2015 , and with the improvements to the X-ray spectrometer, as described by Mejía-Ponce et al. (2018), it was possible to extend to 19 elements: $\mathrm{Na}, \mathrm{Mg}, \mathrm{Al}$, $\mathrm{Si}, \mathrm{P}, \mathrm{S}, \mathrm{Cl}, \mathrm{K}, \mathrm{Ca}, \mathrm{Ti}, \mathrm{V}, \mathrm{Cr}, \mathrm{Mn}, \mathrm{Fe}, \mathrm{Ni}, \mathrm{Cu}, \mathrm{Zn}, \mathrm{Se}$, and $\mathrm{Pb}$. Moreover, detection limits were better for 2016 and 2019 sampling campaigns. Experimental uncertainties in these concentrations were evaluated according to the method described by Espinosa et al. (2010). Regarding ionic concentration values, $\mathrm{Mg}^{2+}, \mathrm{Cl}^{-}$in 2016 had concentrations below LOD, $\mathrm{NO}_{3}{ }^{-}$only 6 values above $\mathrm{LOD}, \mathrm{Na}^{+}, \mathrm{K}^{+}, \mathrm{Ca}^{+}$values above in less than $50 \%$ of total samples, while $\mathrm{SO}_{4}{ }^{2-}$ and $\mathrm{NH}_{4}{ }^{+}$were present in more than $50 \%$ of theset, while the small number of appearances of $\mathrm{NO}^{3-}$ did not permit to make any reliable statement about its concentrations and role in the present study.

Afterwards, table I presents mean, median, and standard deviations for the determined concentrations, for the three campaigns. While the 2015 basic statistics complement the results given by Salcedo et al. (2018), the 2016 statistics has been described previously (Hernández-López et al. 2016, Hernández-López et al. 2018). The $\mathrm{PM}_{2.5}$ official Mexican standard (SSA 2014) was never exceeded in 2015 and 2016. Also, the mean and median values for each data set present similarity, entailing a symmetry in the data distributions. The close values of mean and median values in each data set denote a symmetry in the data distributions. These values, along with the $p$ value, $p<0.20$, obtained by a Kolmogorov-Smirnov normality test for $\mathrm{PM}_{2.5}$ of $2016(\mathrm{~N}=63)$, confirm the data behave as a normal distribution; therefore, we could describe it correctly with parametric statistics. 
TABLE I. MEAN AND MEDIAN CONCENTRATIONS IN PM $2.5\left(\mu \mathrm{g} / \mathrm{m}^{3}\right)$.

\begin{tabular}{|c|c|c|c|c|c|c|c|c|c|}
\hline \multirow{2}{*}{ Species } & \multicolumn{3}{|c|}{2015} & \multicolumn{3}{|c|}{2016} & \multicolumn{3}{|c|}{2019} \\
\hline & Mean & Median & S. Dev. & Mean & Median & S. Dev. & Mean $^{\mathrm{a}}$ & Median & S. Dev. \\
\hline Mass & 18.0 & 16.9 & 8.0 & 18.7 & 18.0 & 8.2 & 31.5 & 28.3 & 17.2 \\
\hline $\mathrm{Na}$ & $\mathrm{ND}^{\mathrm{b}}$ & ND & ND & 0.20 & 0.18 & 0.12 & 0.22 & 0.22 & 0.08 \\
\hline $\mathrm{Mg}$ & ND & ND & ND & 0.021 & 0.017 & 0.015 & 0.081 & 0.076 & 0.051 \\
\hline $\mathrm{Al}$ & 0.39 & 0.35 & 0.20 & 0.029 & 0.028 & 0.018 & 0.057 & 0.055 & 0.030 \\
\hline $\mathrm{Si}$ & 1.1 & 0.93 & 0.84 & 0.14 & 0.11 & 0.08 & 0.18 & 0.14 & 0.11 \\
\hline $\mathrm{P}$ & 0.25 & 0.23 & 0.10 & 0.016 & 0.014 & 0.010 & 0.031 & 0.025 & 0.030 \\
\hline $\mathrm{S}$ & 1.91 & 1.73 & 1.13 & 1.35 & 1.33 & 0.80 & 1.33 & 1.2 & 0.76 \\
\hline $\mathrm{Cl}$ & $0.14^{\mathrm{c}}$ & 0.13 & 0.06 & 0.039 & 0.033 & 0.021 & 0.68 & 0.65 & 0.36 \\
\hline $\mathrm{K}$ & 0.17 & 0.16 & 0.10 & 0.18 & 0.18 & 0.09 & 0.60 & 0.63 & 0.26 \\
\hline $\mathrm{Ca}$ & 0.13 & 0.12 & 0.06 & 0.060 & 0.045 & 0.039 & 0.09 & 0.08 & 0.06 \\
\hline $\mathrm{Ti}$ & 0.10 & 0.09 & 0.05 & 0.018 & 0.013 & 0.018 & 0.018 & 0.009 & 0.019 \\
\hline $\mathrm{V}$ & 0.030 & 0.020 & 0.018 & 0.013 & 0.011 & 0.010 & 0.025 & 0.014 & 0.026 \\
\hline $\mathrm{Cr}$ & 0.22 & 0.22 & 0.03 & 0.035 & 0.033 & 0.034 & 0.11 & 0.10 & 0.05 \\
\hline $\mathrm{Mn}$ & 0.11 & 0.10 & 0.02 & 0.022 & 0.018 & 0.017 & 0.091 & 0.079 & 0.054 \\
\hline $\mathrm{Fe}$ & 0.28 & 0.28 & 0.05 & 0.11 & 0.10 & 0.054 & 0.35 & 0.35 & 0.09 \\
\hline $\mathrm{Ni}$ & 0.029 & 0.030 & 0.010 & 0.005 & 0.003 & 0.004 & 0.025 & 0.017 & 0.024 \\
\hline $\mathrm{Cu}$ & 0.039 & 0.040 & 0.015 & 0.016 & 0.010 & 0.028 & 0.020 & 0.008 & 0.024 \\
\hline $\mathrm{Zn}$ & 0.070 & 0.070 & 0.034 & 0.046 & 0.041 & 0.044 & 0.058 & 0.044 & 0.080 \\
\hline $\mathrm{Se}$ & ND & ND & ND & 0.023 & 0.021 & 0.017 & 0.024 & 0.019 & 0.020 \\
\hline $\mathrm{Pb}$ & 0.15 & 0.14 & 0.05 & 0.051 & 0.039 & 0.045 & 0.19 & 0.18 & 0.11 \\
\hline $\mathrm{OC}$ & 9.3 & 9.4 & 1.3 & ND & ND & ND & ND & ND & ND \\
\hline $\mathrm{EC}$ & 1.01 & 0.99 & 0.41 & ND & ND & ND & ND & ND & ND \\
\hline $\mathrm{NH}_{4}{ }^{+}$ & 1.04 & 0.98 & 0.56 & 0.89 & 0.65 & 0.68 & ND & ND & ND \\
\hline
\end{tabular}

${ }^{\mathrm{a}} 12 \mathrm{~h}$ average. ${ }^{\mathrm{b}} \mathrm{ND}=$ not determined. ${ }^{\mathrm{c}} \mathrm{Cl}^{-}$ionic species.

The application of ANOVA to the $\mathrm{PM}_{2.5}$ mass concentrations for the three data sets, showed that 2015 (dry-cold season) and 2016 (dry-warm season) have equal means $(\alpha=0.05, p$ value $=0.65)$, while 2019 (dry-warm season) is significantly different (higher) to 2015 and $2016(\alpha=0.05, p$ value $<0.001$ for both years). The $p$ value is used in the context of null hypothesis testing in order to quantify the idea of statistical significance; in this case, the null hypothesis is that the means are equal. Moreover, it should be noted that 2019 was marked by at least one event of $\mathrm{PM}_{2.5}$ accumulation near the site (SEDEMA 2019), among other events like biomass burning that will be explained in the PMF section, below, which might have caused a bias towards higher mean concentrations.

There is no substantial evidence to confirm a change in $\mathrm{PM}_{2.5}$ concentration between 2015 drycold and 2016 dry-warm seasons (SEDEMA 2016, SEDEMA 2017). Nonetheless, elemental concentrations were, in general, higher during 2015, which is to be expected, according to previous works, due to the accumulation of PM during cold season, along with an increase of elements associated with soil resuspension (Al, Si) and from other anthropogenic activities (Mn, V, Cu) (Aldape et al. 1999, Raga et al. 2001).
As for carbonaceous components, $\mathrm{OC}, \mathrm{EC}$ and total carbon $(\mathrm{TC}=\mathrm{OC}+\mathrm{EC})$ concentrations are plotted in figure 4. Also, table II shows their average concentrations, including a comparison with previous works that measured the same variables from the

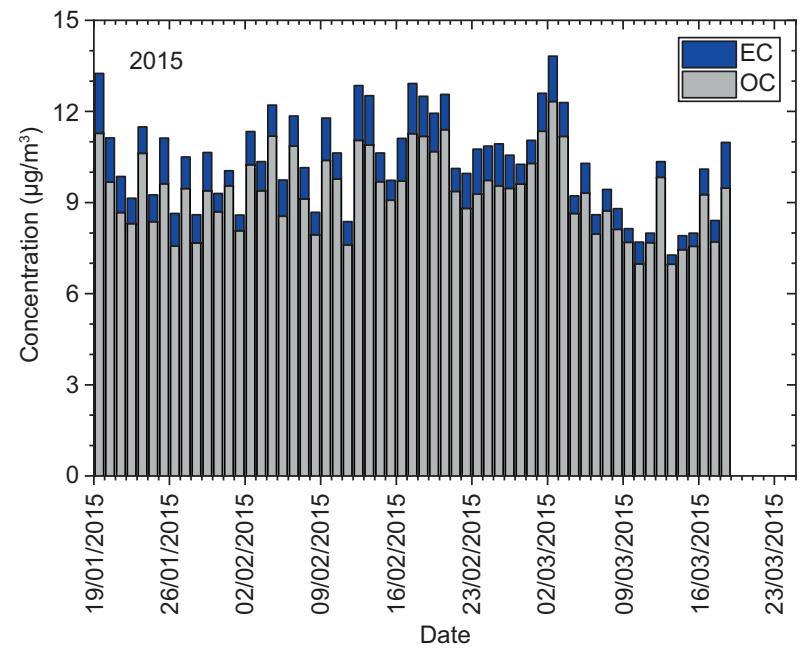

Fig. 4. Time series of $\mathrm{OC}, \mathrm{EC}$ and $\mathrm{TC}(\mathrm{OC}+\mathrm{EC})$ concentrations in $\mathrm{PM}_{2.5}$ at southwest Mexico City during winter 2015. 
TABLE II. ORGANIC CARBON (OC), ELEMENTAL CARBON (EC) AND TOTAL CARBON (TC) CONCENTRATIONS $\left(\mu \mathrm{g} / \mathrm{m}^{3}\right)$ AT THE SOUTHWEST SITE DURING 2015, AND COMPARISON WITH PREVIOUS WORKS PERFORMED AT THE SAME AREA.

\begin{tabular}{llrll}
\hline Year & Reference & OC & EC & TC \\
\hline 1997 & Chow 2002 & 7.62 & 2.89 & 10.5 \\
2001 & Vega 2004 & 13.88 & 3.81 & 17.7 \\
2003 & Vega 2011 & 8.80 & 3.79 & 12.6 \\
2004 & Vega 2011 & 7.31 & 2.85 & 10.2 \\
2015 & This work & 9.3 & 1.01 & 10.3 \\
\hline
\end{tabular}

southwestern area (Chow et al. 2002, Vega et al. 2004, Vega et al. 2011). The daily concentrations of OC in 2015 ranged between $4.48 \pm 0.31 \mu \mathrm{g} / \mathrm{m}^{3}$ and $12.33 \pm$ $0.73 \mu \mathrm{g} / \mathrm{m}^{3}$, while EC contents varied between 0.43 $\pm 0.17 \mu \mathrm{g} / \mathrm{m}^{3}$ and $7.28 \pm 0.27 \mu \mathrm{g} / \mathrm{m}^{3}$, respectively. OC represented $80 \%$ to $93 \%$ of the TC in the $\mathrm{PM}_{2.5}$ samples. In the average, OC contributes with $63 \%$ to total gravimetric mass, while EC represents $6 \%$.

In order to associate this high value of $\mathrm{OC}$ to secondary sources of $\mathrm{PM}_{2.5}$, the $\mathrm{TC} / \mathrm{EC}$ ratio was evaluated. TC to EC ratios have been widely used to identify the presence of an organic carbon enrichment in $\mathrm{PM}_{2.5}$, commonly associated to the formation of secondary organic aerosol (SOA) (Gray et al. 1986, Kadowaki et al. 1990, Turpin et al. 1995). The elemental carbon present in the atmosphere is produced by primary emission, it is inert and non-volatile; therefore, the concentration of EC in the atmosphere is relatively stable. Conversely, $\mathrm{OC}$ can be emitted by primary sources, but can also be formed by secondary reactions in the atmosphere, leading to the formation of SOA. So, if a large fraction of $\mathrm{PM}_{2.5}$ is contributed by SOA, the TC/EC ratio should exceed that found in primary sources emissions. Commonly TC/EC values for primary emissions are estimated to be close to 3 , e.g. the average TC/ECfor highway traffic emissions is anticipated to be 3.2 , so $\mathrm{PM}_{2.5}$ contributed by SOA are expected to have a value larger than 3 .

Another relationship that provides information about the presence of SOA is the OC vs EC correlation (Chow et al. 2002, Mugica et al. 2009, GuzmánTorres et al. 2009, Ramírez et al. 2018); if OC and EC came from the same emission source, it would be expected that both species were correlated. Calculated values of TC/EC ranged between 2.29 (1.3) and 20 (16) with a median value of 8.95 (0.93), suggesting a significant contribution of OC due to SOA formation. Additionally, there is a poor determination coefficient, $R^{2}=0.099$, between OC and EC, with a high intercept value of $8.06(0.38) \mu \mathrm{g} / \mathrm{m}^{3}$. It supports the previous assumption, at the receptor site, southwest of Mexico City, that a large fraction of the $\mathrm{PM}_{2.5}$ is aided by SOA formation.

Regarding the comparison of measured elemental concentrations from previous studies with the present work, figure 5 displays the $\mathrm{PM}_{2.5}$ gravimetric mass and two representative elements ( $\mathrm{S}$ and $\mathrm{Pb}) 24 \mathrm{~h}$ mean concentrations in the southwest area of the MCMA, from other publications (Paredes et al. 1997, Miranda et al. 1998, Miranda et al. 2000, Chow et al. 2002, Aldape and Flores 2004, Miranda et al. 2004, Vega et al. 2004, Miranda et al. 2005, Vega et al. 2011, Morton-Bermea et al. 2018b, Garza-Galindo et al. 2019). Values for 2019 refer to $12 \mathrm{~h}$ averages, while those from Miranda et al. (1996) are $6 \mathrm{~h}$ averages.

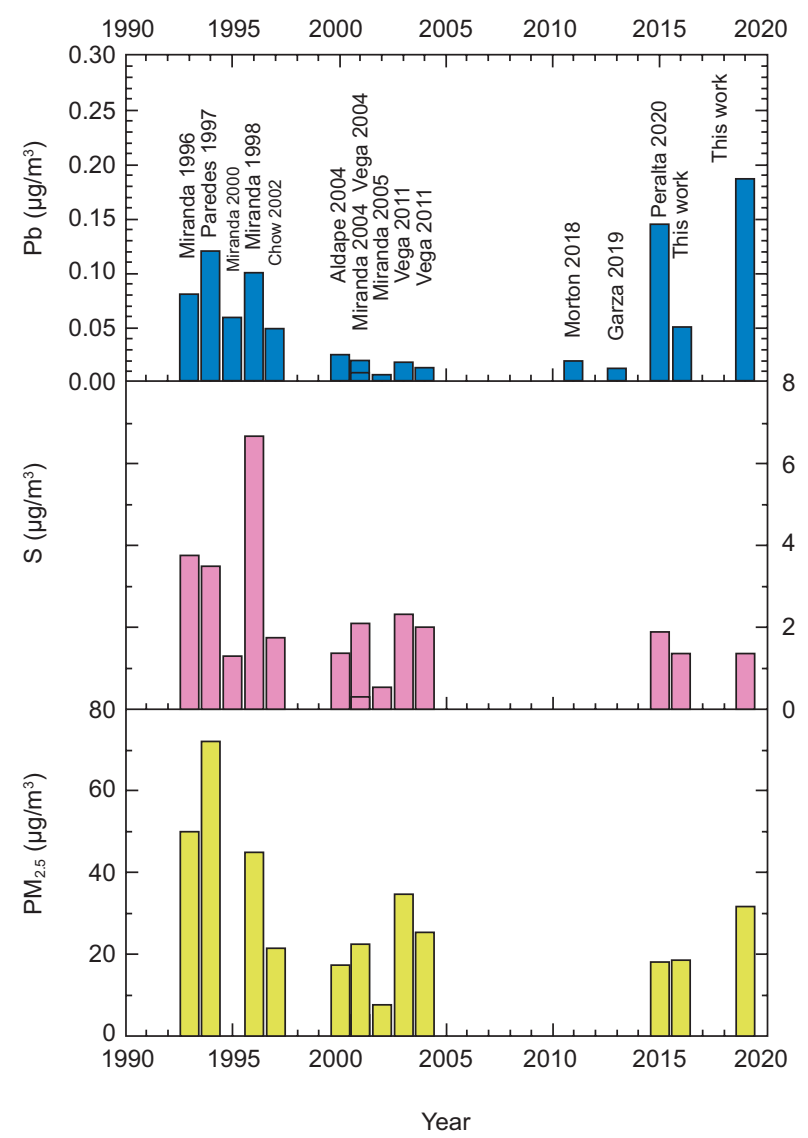

Fig. 5. $\mathrm{PM}_{2.5}$ gravimetric mass, $\mathrm{S}$, and $\mathrm{Pb} 24 \mathrm{~h}$ mean concentrations in the southwest area of the MCMA, from previous publications (Paredes et al. 1997, Miranda et al. 1998, Miranda et al. 2000, Chow et al. 2002, Aldape and Flores 2004, Miranda et al. 2004, Vega et al. 2004, Miranda et al. 2005, Vega et al. 2011, Morton-Bermea et al. 2018b, Garza-Galindo et al. 2019). Data for 2019 refer to $12 \mathrm{~h}$ averages and Miranda et al. (1996) are $6 \mathrm{~h}$ averages. 
The first observation is the large time gap (11 years) since the last published measurements, except for $\mathrm{Pb}$, emphasizing the need to keep on continuous studies. $\mathrm{PM}_{2.5}$ mass and $\mathrm{S}$ concentrations have not changed significantly since the last studies.

It must be noted that the amounts of $\mathrm{Pb}$ are notably larger than in the past, pointing out to a situation that requires immediate attention; possible explanations are either a local source or a contribution of biomass burning, as obtained with the PMF analysis below. The explanation of why the existence of a local $\mathrm{Pb}$ source is suspected can be found in the supplementary material (section S4). All these facts together support the existence of a local, unidentified source, although $\mathrm{Pb}$ contents did not exceed the Mexican official standard $\left(1.5 \mu \mathrm{g} / \mathrm{m}^{3}\right.$, three-months average) (SSA 1993).

Concerning the comparison between morning and afternoon periods during 2019, applying a simple analysis of variance, or ANOVA (Kreyszig 1970) to the morning and afternoon gravimetric mass and the most relevant elements ( $\mathrm{Al}, \mathrm{Si}, \mathrm{S}, \mathrm{K}, \mathrm{Ca}, \mathrm{Fe}, \mathrm{Zn}$, and $\mathrm{Pb}$ ), it was found that all means were equal with $\alpha=0.01$, except for $\mathrm{Ca}\left(0.11 \pm 0.06 \mu \mathrm{g} / \mathrm{m}^{3}\right.$ in the morning to $0.069 \pm 0.048 \mu \mathrm{g} / \mathrm{m}^{3}$ in the afternoon, $p$ value $=0.002), \mathrm{Fe}\left(0.39 \pm 0.08 \mu \mathrm{g} / \mathrm{m}^{3} / 0.30 \pm 0.07\right.$ $\mu \mathrm{g} / \mathrm{m}^{3} ; p$ value $\left.<0.001\right)$, and $\mathrm{Pb}\left(0.24 \pm 0.17 \mu \mathrm{g} / \mathrm{m}^{3}\right.$ $/ 0.12 \pm 0.07 \mu \mathrm{g} / \mathrm{m}^{3} ; p$-value $\left.<0.001\right)$. Probably, the fact that $\mathrm{Ca}$ and $\mathrm{Fe}$ elements had higher concentrations is due to a lack of atmospheric circulation, with possible occurrence of inversion layers, which limited the dissipation of air pollutants from the surface (Guzmán-Torres et al. 2009). In the case of $\mathrm{Pb}$, as the existence of a local source was proposed, it may have a stronger activity during the morning periods. Another explanation may be the presence of a larger number of motor vehicles during the early day periods. Figure 6 presents a comparison of the morning/afternoon average concentrations in 2019 and those determined in 1995 (Miranda et al. 2000), at the same sampling site and time resolution. While some geogenic elements (Al, $\mathrm{Si}, \mathrm{Ti}, \mathrm{Ca})$ presented lower concentrations in 2019, other anthropogenic species ( $\mathrm{V}, \mathrm{Cr}, \mathrm{Mn}, \mathrm{Pb}$ ) had an important increase, which might be related, as said above, to vehicle traffic in the area. Also, $\mathrm{Cl}$ and $\mathrm{K}$ presented a growth, possibly associated to the strong contribution of biomass burning in 2019, as will be explained below. Finally, $\mathrm{S}$ and Fe had similar values in both studies.

A simple way to recognize geogenic provenance of the elements is the use of enrichment factors (EF), taking as a reference a crustal element (Lawson and Winchester 1967). The EF compares the relative concentration of an element in the airborne particles

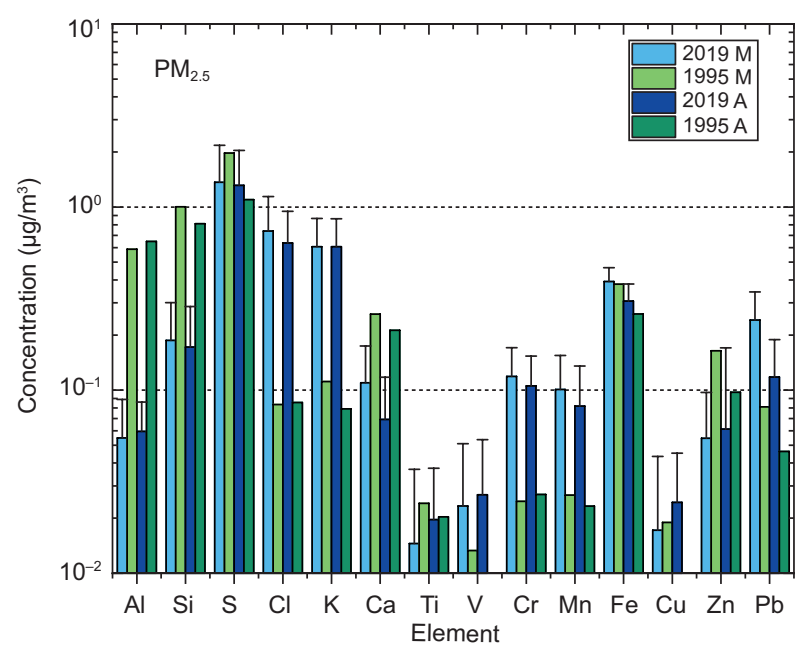

Fig. 6. Comparison of the $\mathrm{PM}_{2.5}$ morning/afternoon average elemental concentrations in 2019 and those measured in 1995 (Miranda et al. 2000), at the same sampling site and time resolution $(6 \mathrm{~h})$.

to that in crustal material and it has been used to evaluate whether its presence in PM is due to crustal or non-crustal sources (Méndez-García et al. 2017, Rodriguez-Espinosa et al. 2017, Shruti et al. 2018). Values of EF close to 1 suggest the element in the PM may have a significant fraction contributed by a crustal source. In the present study, Si was chosen as reference, due to the low uncertainty and large sensitivity of the detection system for this element. Using concentrations of the average Earth crust from the public web site Lumen (2018), figure 7 contains the EF for the detected elements in 2015, 2016, and

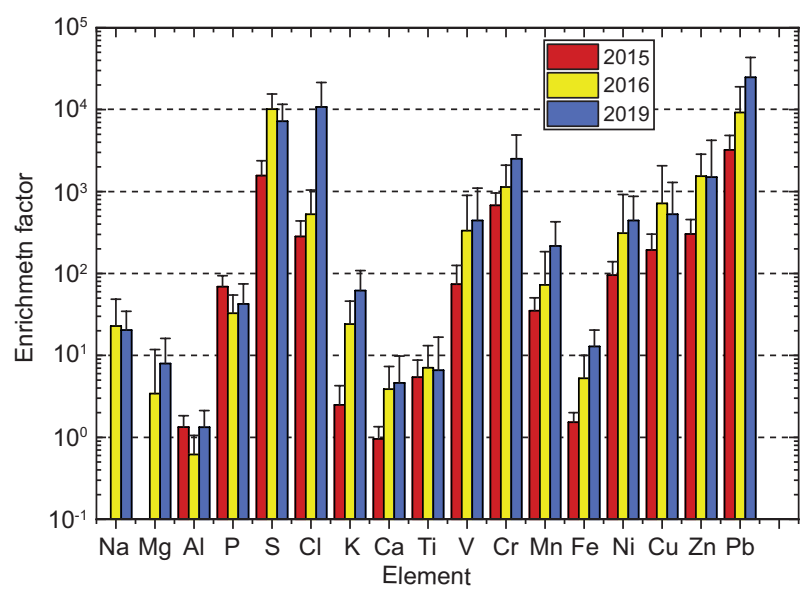

Fig. 7. Average enrichment factors for elements found in the three sampling periods. Si was used as a reference element. 
2019. Elements with $\mathrm{EF} \leq 10$ can be considered as geogenic, while those above this value have a different source. Thus, crustal elements in this case are, as expected, $\mathrm{Mg}, \mathrm{Al}, \mathrm{K}$ (in 2015), $\mathrm{Ca}, \mathrm{Ti}$, and $\mathrm{Fe}$. It must be kept in mind that the EF do not provide information on the specific emitting source. For instance, $\mathrm{K}$ and $\mathrm{Fe}$ in 2019 may also receive other contributions, such as biomass burning or industry (Barrera et al. 2012). Other elements ( $\mathrm{S}, \mathrm{V}, \mathrm{Cr}, \mathrm{Mn}, \mathrm{Ni}, \mathrm{Cu}, \mathrm{Zn}$, $\mathrm{Pb}$ ) have undoubtedly anthropogenic sources (fuel oil burning, industry, vehicular traffic) (Miranda et al. 1994).

\section{Meteorological data}

Another important variable that affects the $\mathrm{PM}_{2.5}$ concentrations and composition at the receptor site is wind. Figure 8 shows monthly wind roses for each campaign; the plots for 2019 only contain data between 7:00 $\mathrm{h}$ and 19:00 h (local time), covering the sampling days. It is apparent that the wind roses in 2015 and 2016 are similar, with calm winds almost the entire periods, having dominant directions from west and southwest (more intense) in March, 2016, while the one in 2019 is very different, from southwest or northeast, slightly more intense in the average. Possible effects of the wind regimes will be discussed below, in relationship to PMF results.

\section{Receptor models}

Recognizing the need to accurately identify the pollutant sources in each sampling campaign, as well as the corresponding contributions, PMF receptor modeling (Paatero and Tapper 1994) was applied to the three data sets, separately, using the EPA-PMF 5.0 open access software (EPA 2014). Only Johnson et al. (2006) and Barrera et al. (2012) had used PMF at MCMA for elemental analyses data, although the first work used size-resolved particle records from a different sampling site (southeast), and the latter was based on $\mathrm{PM}_{10}$ results.

For the present study, the 2015 data set excluded $\mathrm{OC}$ and EC concentrations, in order to facilitate the comparison among the three campaigns, as the concentrations of these species were not determined in 2016 and 2019. However, $\mathrm{NH}_{4}{ }^{+}$was kept for 2015 and 2016. Thus, table III summarizes the statistical assessment of the PMF modeling for the three data sets; the number of iterations for each run were 100 with five factors for all years. The number of valid cases is presented, with $Q_{\text {True }}, Q_{\text {Robust }}$, and the repeatability/stability. Although also rotations with $F= \pm$ 0.5 and $F= \pm 1.0$ were attempted, no remarkable improvements in the factors were observed. Figure 9 presents the source profiles obtained for each year.

It is remarkable that for the three years there is an agreement in the proposed factors. The association of the factors with contributing sources is carried out on the basis of the chemical species and relative contributions of each one to the factors. As a result, it can be seen that the identified sources were soil, sulfate, soil + sulfate, biomass burning, and an industry/traffic source.

The soil source is labeled through the high contents of geogenic elements $\mathrm{Al}, \mathrm{Si}, \mathrm{Ca}, \mathrm{Ti}$, and $\mathrm{Fe}$, in agreement with the above EF determinations; the small V contribution to this source in 2019 was also observed in other studies (Garza-Galindo et al. 2019), attributed to a mixture of geogenic and anthropogenic emissions. Biomass burning was identified through the presence of $\mathrm{K}$, which is a tracer of this source (Miranda et al. 1998, Barrera et al. 2012). The soil+sulfate factor has been observed previously in several studies (Miranda et al. 1996, Miranda et al. 2005, Barrera et al. 2012, Díaz et al. 2014). Following a hypothesis presented by Barrera et al. (2012), it is feasible that crustal airborne particles are subjected to chemical reactions with atmospheric $\mathrm{SO}_{2}$, producing these S-enriched geogenic particles. The industry/traffic factor contains anthropogenic elements, like $\mathrm{Cr}, \mathrm{Mn}$ or $\mathrm{Zn}$. It must be noted that $\mathrm{Cr}$ concentrations during 2016 were too low (see also Table I), so the PMF model development excluded this element. The sulfate factor includes $\mathrm{S}$ and $\mathrm{NH}_{4}{ }^{+}$in 2015 and 2016, making it easier to identify the factor in 2019.

Then, the apportionment of each source to total gravimetric mass is presented in table IV.

The explanation of the role of each factor in every campaign starts with the soil source. In 2015 the factor contributed with $3 \%$ of the total gravimetric mass, decreasing to $0.6 \%$ and $1.7 \%$ in 2016 and 2019, respectively. This may be due to the fact that 2015 corresponds to the dry-cold season, as compared to warm-dry seasons of the other two campaigns. Based on the rose winds from figure 8 , there seems to be no influence of the wind direction or speed on this source for this study, although it has been observed in other works (Miranda et al. 2000). In comparison, the contribution of a soil source identified with APCA in a 1993 study (Miranda et al. 1996) accounted for nearly $8 \%$ of the total gravimetric mass, and in 2002 (Miranda et al. 2005) it was $3.1 \%$, similar to those in the present work. In this aspect, it can be said that the contributions diminished since 1993, but are kept nearly constant in the latter years. 


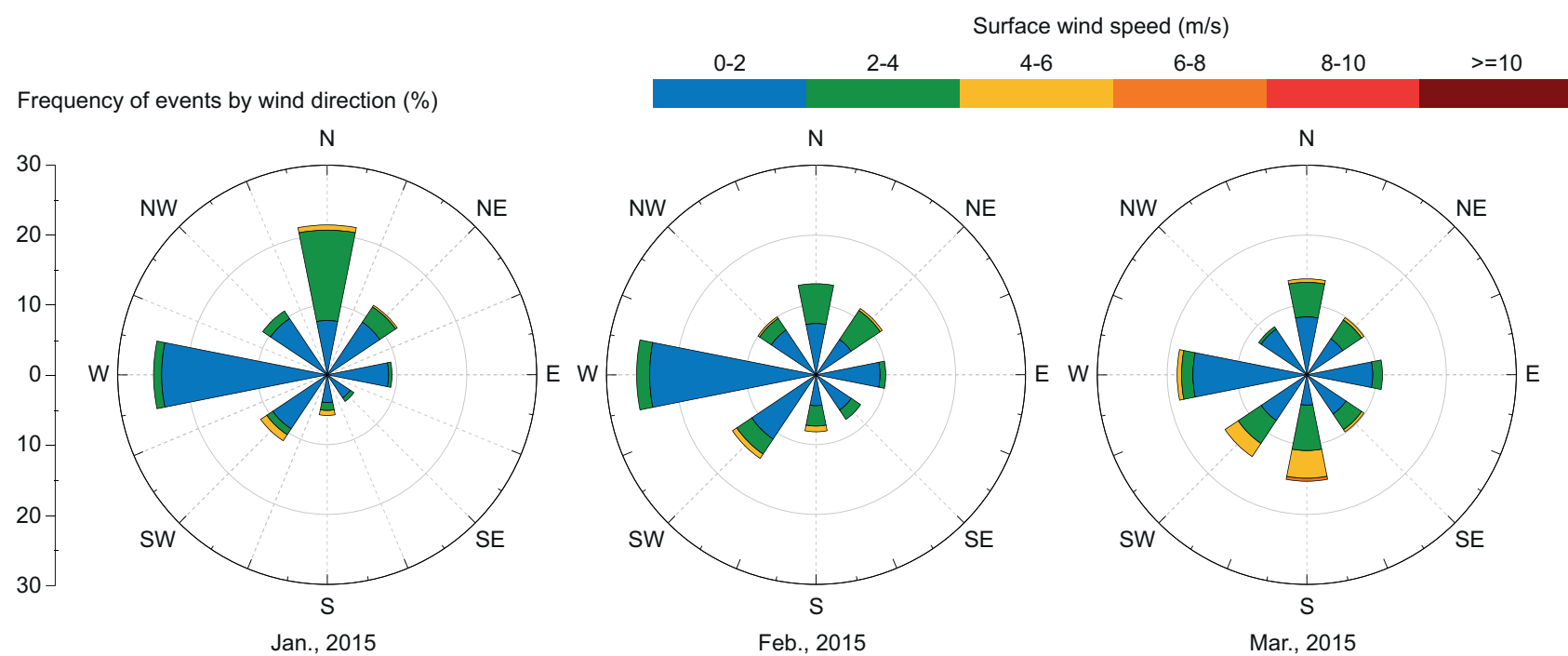

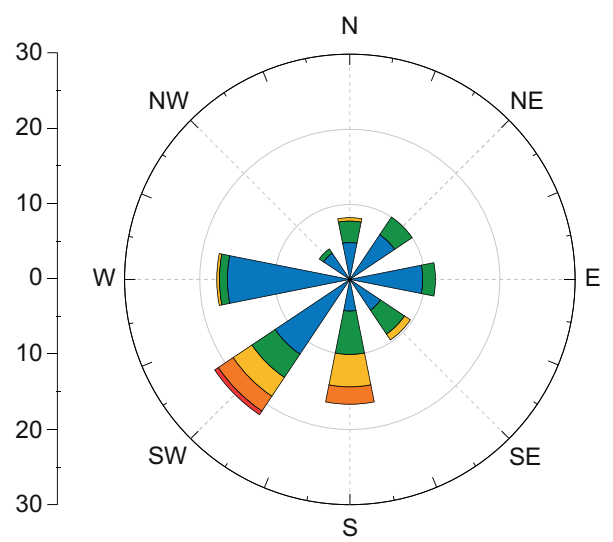

Mar., 2016

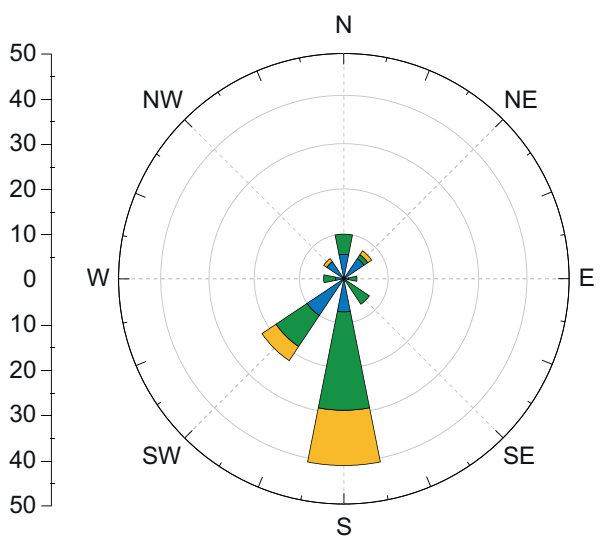

Mar., 2019 (07:00-19:00 hrs.)

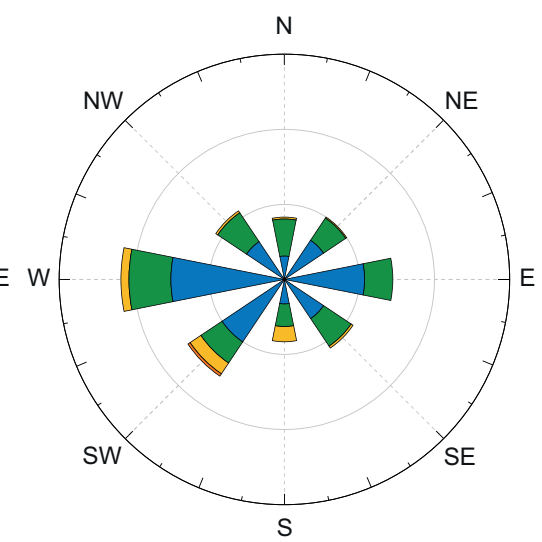

Apr., 2016

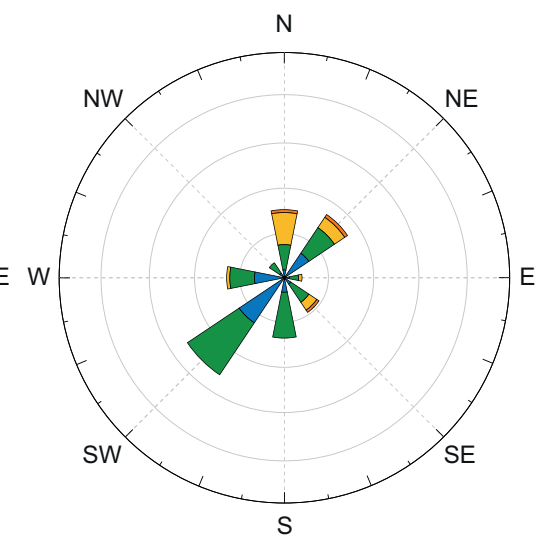

Apr., 2019 (07:00-19:00 hrs.)

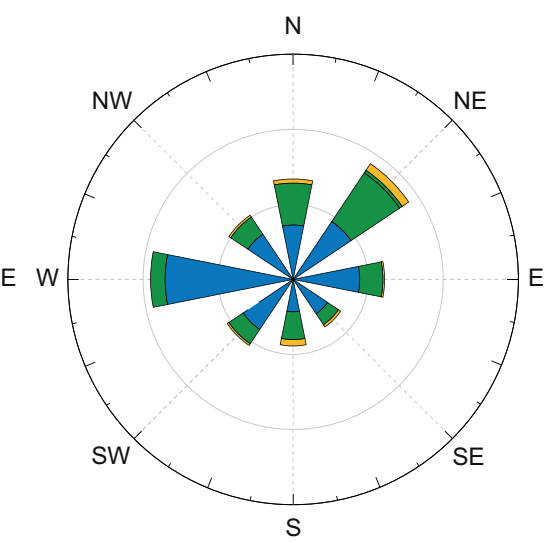

May., 2016

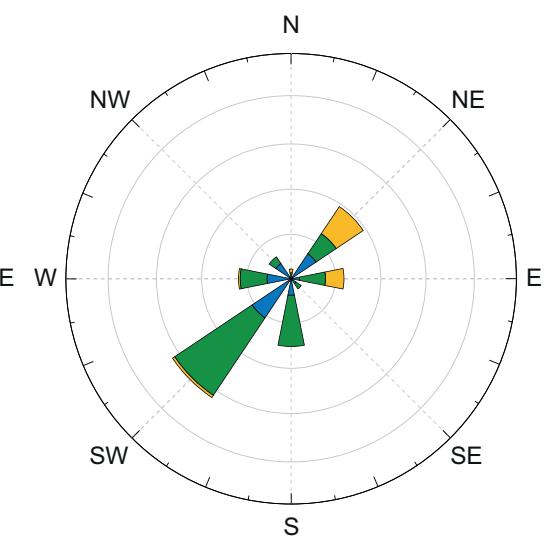

May., 2019 (07:00-19:00 hrs.)

Fig. 8. Wind roses during the 2015, 2016, and 2019 sampling campaigns. Data were obtained through the REDMET network at the UNAM site (SEDEMA 2020a). 
TABLE III. DESCRIPTION OF PMF RESULTS.

\begin{tabular}{lccrrccc}
\hline Year & Factors & Valid $N$ & $Q_{\text {True }}$ & $Q_{\text {Robust }}$ & DISP & BS & BS-DISP \\
\hline 2015 & 5 & 63 & 3191.9 & 1496.9 & Stable & Reproducible & Constrained \\
2016 & 5 & 52 & 159.3 & 159.3 & Stable & Reproducible & Constrained \\
2019 & 5 & 89 & 1741.8 & 1612.4 & Stable & Reproducible & Constrained \\
\hline
\end{tabular}

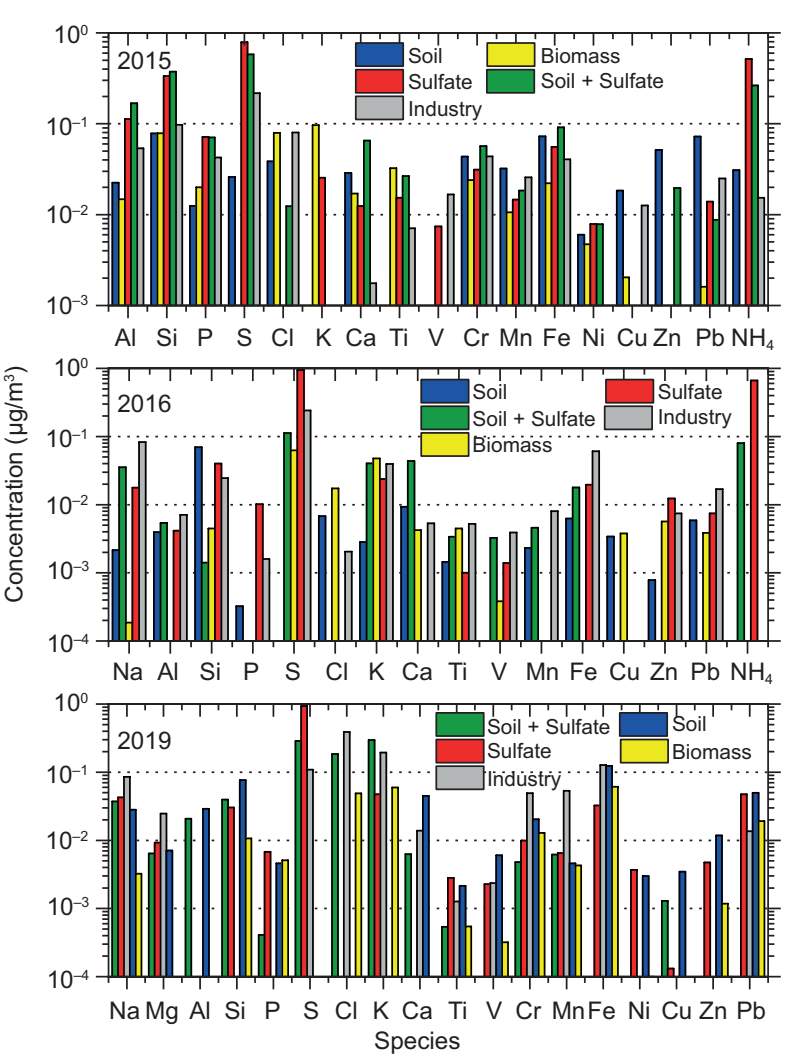

Fig. 9. Source profiles for each year as determined with PMF receptor modelling.

TABLE IV. CONTRIBUTION OF EACH FACTOR TO TOTAL GRAVIMETRIC MASS.

\begin{tabular}{cccccc}
\hline Year & $\begin{array}{c}\text { Soil } \\
(\%)\end{array}$ & $\begin{array}{c}\text { Sulfate } \\
(\%)\end{array}$ & $\begin{array}{c}\text { Soil+ sulfate } \\
(\%)\end{array}$ & $\begin{array}{c}\text { Biomass } \\
(\%)\end{array}$ & $\begin{array}{c}\text { Industry } \\
(\%)\end{array}$ \\
\hline 2015 & 3.0 & 11 & 9.3 & 2.1 & 3.6 \\
2016 & 0.6 & 9.4 & 1.9 & 0.8 & 2.7 \\
2019 & 1.7 & 3.8 & 2.8 & 3.7 & 1.4 \\
\hline
\end{tabular}

Regarding the sulfate factor in 2015 and 2016, figure 10 shows the relationship between the ionic species $\mathrm{NH}_{4}{ }^{+}$and elemental $\mathrm{S}$ concentrations used by the PMF model, demonstrating and excellent correlation, except for a few points with a S enrichment, which were neglected in the fit. As in the case

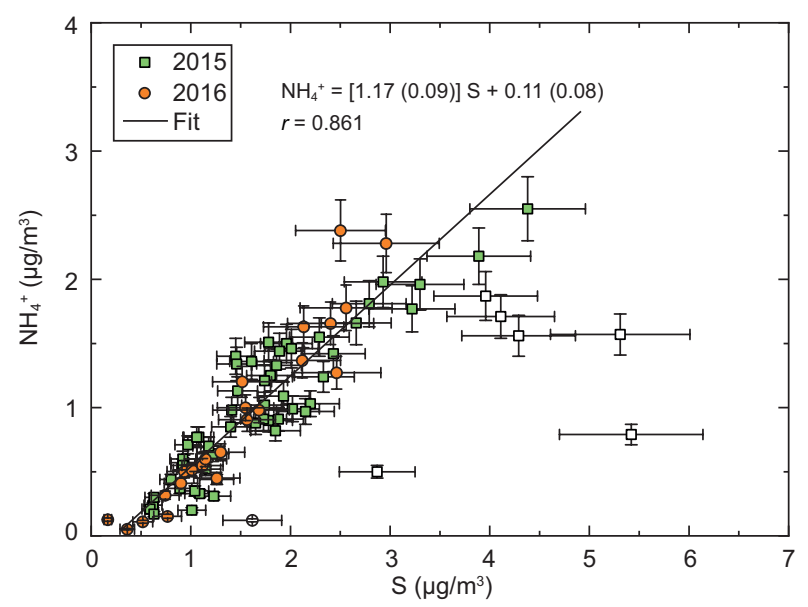

Fig. 10. Relationship between $\mathrm{NH}_{4}{ }^{+}$and $\mathrm{S}$ concentrations for 2015 and 2016 campaigns. The white experimental points were neglected in the fit, assuming an excessive $\mathrm{S}$ presence in the samples.

discussed above, for the data in figure $\mathbf{3}$, this excess may be attributed to other ionic species different than $\left(\mathrm{NH}_{4}\right)_{2} \mathrm{SO}_{4}$, for example $\mathrm{SO}_{2}$ and other compounds found in low concentrations (Saxena and Seigneur 1989, Ye at al. 2014). This strong association between $\mathrm{S}$ and $\mathrm{NH}_{4}{ }^{+}$has been found previously (Edgerton et al. 1999, Vega et al. 2011), and is explained by a gasto-particle conversion process, producing secondary aerosols like $\left(\mathrm{NH}_{4}\right)_{2} \mathrm{SO}_{4}$. Another evidence of the sulfate origin of this source is given in figure 11, where the association between sulfate values predicted by $\mathrm{PMF}$ and the concentration of $\mathrm{SO}_{4}{ }^{2-}$ in samples analyzed by IC in 2016 show a positive correlation; this fact supports the assertion that this PMF factor is undoubtedly due to sulfate. The probability that these two variables are not correlated is lower than $1 \%$, based on the number of points and the high correlation coefficient (Taylor 1997). Moreover, the contribution of the sulfate source during 2015 and 2016 (Table IV) is larger than that of 2019, because the $\mathrm{NH}_{4}{ }^{+}$ionic species was not measured in that year. Nonetheless, if an extrapolation of this contribution is carried out to add the $\mathrm{NH}_{4}{ }^{+}$mass in the ammonium sulfate molecule, the sulfate factor proportion increases to nearly $8 \%$ in 2019 , of the same order as 


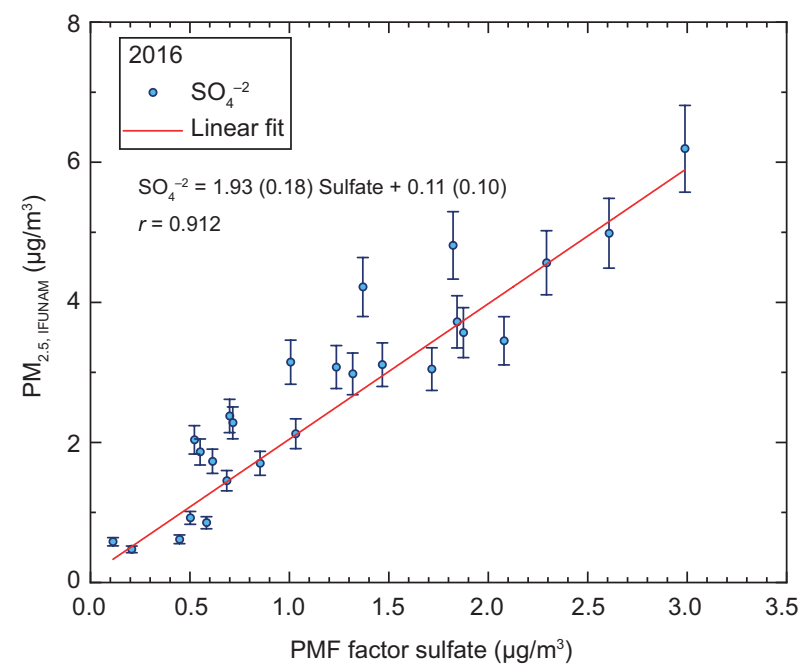

Fig. 11. $\mathrm{SO}_{4}{ }^{2-}$ concentrations as a function of the sulfate factor concentrations obtained with PMF with 2016 data.

those of 2015 and 2016. A study carried out in 2002 (Miranda et al. 2005) presents a similar factor to the sulfate in 2019 , contributing with $2.1 \%$ to the total mass; considering the particular atmospheric conditions in 2019, it seems there is a concordance in the order of magnitude of these contributions.

A relationship between the soil and soil + sulfate is also observed: in 2016 there is strong reduction of the latter source as compared to 2015 (9.3\% to $1.9 \%)$. However, the soil factor was also reduced in nearly the same proportion $(3.0 \%$ to $0.6 \%)$. Thus, there should be less soil derived particles available for the S-enrichment process in the atmosphere, to produce the soil + sulfate aerosol.

In contrast to the sampling campaigns in 2015 and 2016, the 2019 one was especially marked by an intense $\mathrm{PM}_{2.5}$ pollutant event at the MCMA, reaching levels above the official Mexican standard, so it was necessary to declare a contingency status in the urban area (SEDEMA 2019). The episode took place between May 12 and May 18, 2019, which was clearly recognized during this study. Therefore, figure 12 presents the $\mathrm{PM}_{2.5}$ time series, including the $45 \mu \mathrm{g} / \mathrm{m}^{3}$ Mexican standard (SSA 2014) and the $25 \mu \mathrm{g} / \mathrm{m}^{3}$ World Health Organization standard (WHO 2005); the emergency period is indicated in gray. Additionally, the PMF model provides an explanation of the main source of the particulate matter during the episode.

Figure 13 displays the time series of the biomass burning factor as well as the detected fire spots during that week in the country, according to the FIRMS database (Justice et al. 2002); noticeably, there is a

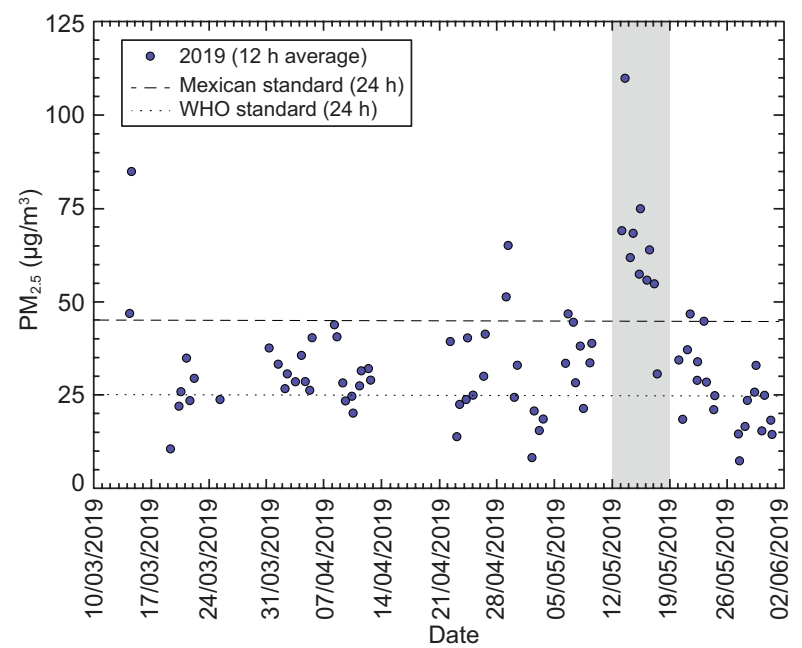

Fig. 12. Time series of $12 \mathrm{~h} \mathrm{PM}_{2.5}$ gravimetric mass concentrations measured in the present work during 2019. The contingency period is marked in gray, and the official Mexican and WHO standards are displayed.

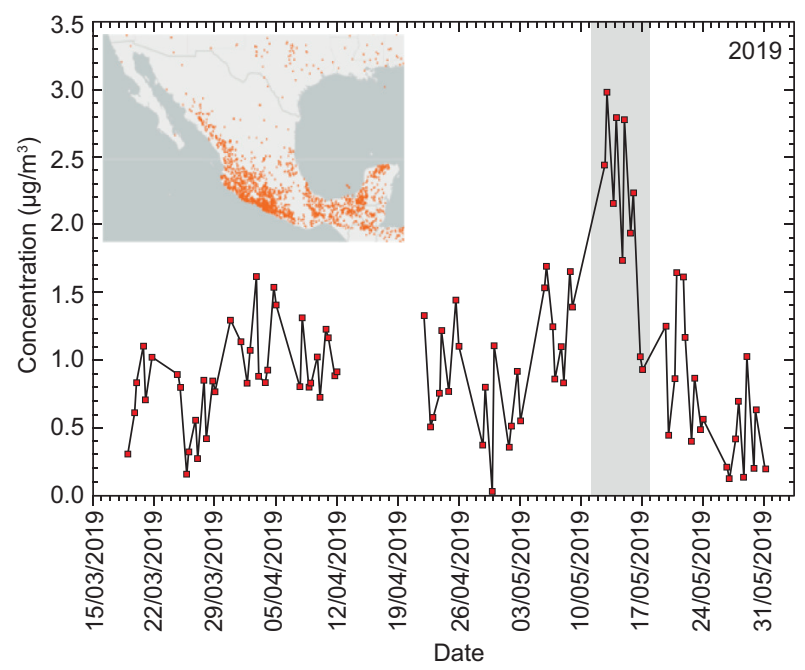

Fig. 13. Time series of the biomass burning factor obtained with PMF of the 2019 sample set. The contingency period is marked in gray, while the insert shows the fire spots identified by the FIRMS database (Justice et al. 2002).

peak during the same period. The spots correspond to both forest fires and intentional agricultural burning. Additionally, the wind rose corresponding to May, 2019 in figure 8 presents prevalent winds from the southwest, the region where the fire spots density seems to be higher.

Finally, figure 14 shows a scheme of the threedimensional winds as determined by the RUOAUNAM Lidar (Peralta et al. 2016), for May 14, 2019, a day in the middle of the emergency period. 


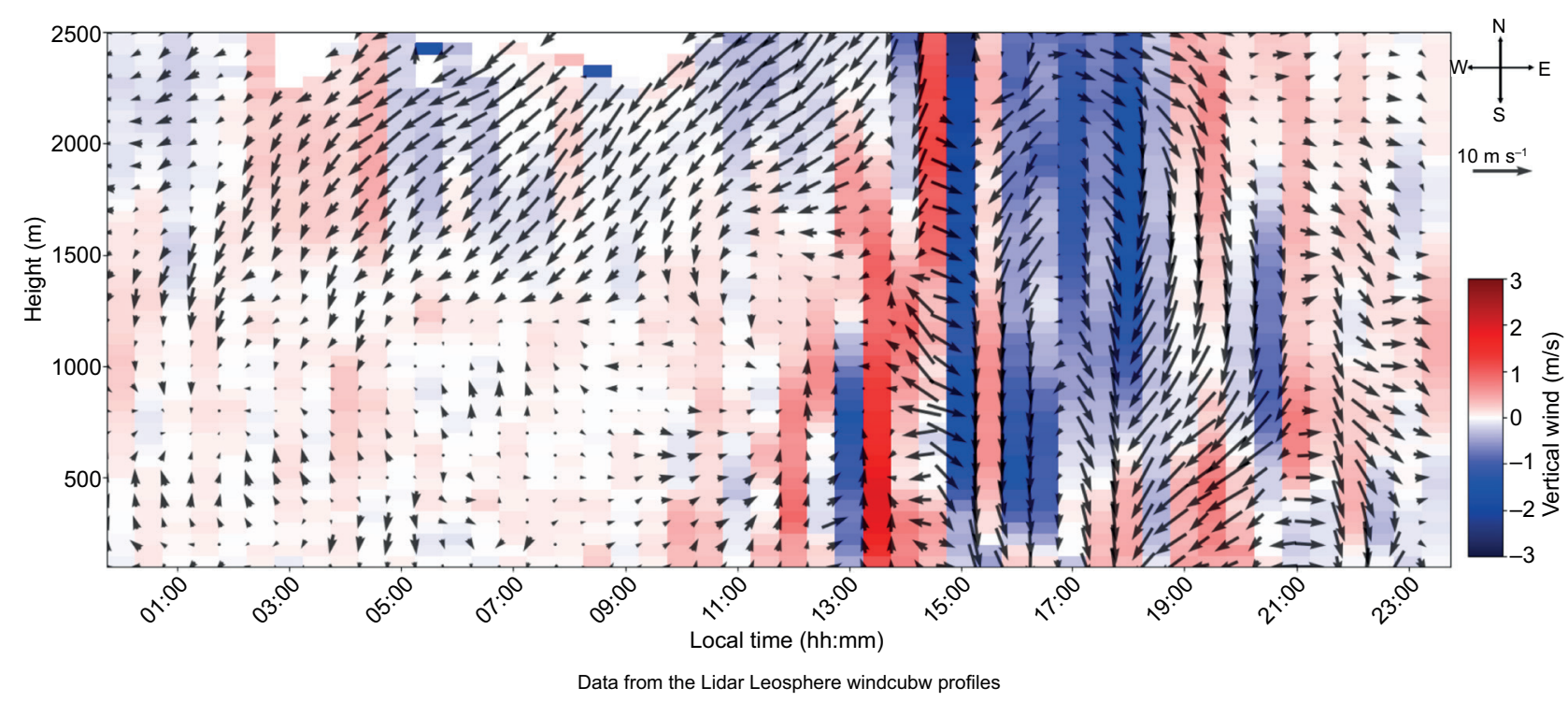

Fig. 14. Scheme of three-dimensional winds as determined by the Lidar Leosphere Windcube profiler, located at the CCA site of the Red Universitaria de Observatorios Atmosféricos de la Universidad Nacional Autónoma de México, RUOA-UNAM (Peralta et al. 2016), for May 14, 2019.

As can be seen, the winds were not only mostly calm during the morning period in the horizontal plane, but the vertical winds seemed to concentrate the pollutants in the lower altitudes during the afternoon interval.

All these results explain the biomass burning origin of the extreme event during 2019 at the MCMA, while the winds during 2015 and 2016, related to the PMF source behavior, did not show any particular event. This supports the potential of XRF elemental analyses plus PMF for the identification of the biomass burning source.

There is a fifth factor, containing many anthropogenic elements (V, Cr, Mn, Fe, Zn, Pb). Possible contributors are industry and/or vehicular emissions, in agreement with vehicular traffic increase in the area, although the use of leaded gasoline was banned in the MCMA since the early 1990s. Moreover, a local $\mathrm{Pb}$ source might be affecting the PM composition, as explained above and in the Supplementary material. Nevertheless, it is important to note that the contribution of this factor to total mass is very similar during the three years. Thus, no significant variation in terms of air quality in the studied area is observed along the studied period (2015-2019). The industry contributions, nevertheless, are similar to those measured in 1993 (Miranda et al. 1996), which is of the order of $4 \%$, but higher than the result in 2002, around $1 \%$ (Miranda et al. 2005). Thus, an evident trend cannot be found.
Large scientific evidence about the adverse health effects of particles has been reported in the last twenty-five years, such as daily increments of around $1 \%-2 \%$ in cardiovascular mortality for every $10 \mu \mathrm{g} /$ $\mathrm{m}^{3}$ increase in $\mathrm{PM}_{2.5}$ which has been confirmed in Mexico City, where findings show that brain-vascular mortality seems to be larger than those reported in other continents and North America, with an increase of $3.19 \%$ (IC95 \% 0.44-6.01) and 3.37\% (IC95 \% 0.09-6.76) in people older than 65 years (BorjaAburto et al. 1998, Atkinson et al. 2014, GutiérrezÁvila et al. 2018) whereas Calderón-Garcidueñas et al. (2015) reported the effects on central nervous system in infants and young children due to ozone and $\mathrm{PM}_{10}$. Additionally, Choi et al. (2018) indicated that PM is hazardous for human health since is considered a major non-infectious cause of severe acute exacerbation of chronic obstructive pulmonary disease (COPD). The comparison of mass concentrations displayed in figure 5 shows that despite the efforts of Mexico City authorities, inhabitants remain exposed to $\mathrm{PM}_{2.5}$; therefore, continuous studies related with monitoring and characterization of PM are necessary. The experiments must consider not only gravimetric mass concentrations, but also the chemical composition and the identification of the polluting sources.

Regarding the behavior of $\mathrm{PM}_{2.5}$ during 2019, the high concentrations during May had an important effect in the air quality. As explained above, it was necessary to declare a contingency, because 
the official standards were surpassed, exposing the inhabitants to a health risk. The present work offered an explanation of the origin of the particles during the event (biomass burning). The rest of the sources did not have a relevant effect on this phenomenon. Also, the concentrations during the sampling periods in 2015 and 2016 were not too high, keeping levels below the official standards.

\section{CONCLUSIONS}

The Mexico City Metropolitan Area is still one of the most studied places in the world regarding air quality, with great significance in this scientific area. The present work comprises results of elemental analyses of $\mathrm{PM}_{2.5}$ samples collected in three periods during the years 2015, 2016, and 2019, in a major interest site of the MCMA. The need to continue with this kind of studies is justified by the large time gap elapsed from the previous works on elemental analyses, the demographic changes in the southwest area of the city, and the observed change in the concentration of elements like $\mathrm{Pb}$, which might be attributed to a local source. Other variables remained virtually unchanged, as is the case of gravimetric mass. It was demonstrated that only $\mathrm{Ca}, \mathrm{Fe}$, and $\mathrm{Pb}$ varied significantly between morning and afternoon intervals in 2019. Thus, the air quality does not, in general, seem to be strongly modified since the last studies were carried out. The analytical methods proved to be accurate and adequate, in particular for the development of receptor models. Also, the fractional contributions of OC and EC could be estimated and explained for only one of the campaigns. PMF allowed the identification of the same sources for the three data sets, similar to those found in previous studies. With the aid of ion chromatography and PMF, it was possible to verify the presence of secondary aerosols containing $\mathrm{S}$ and $\mathrm{NH}_{4}{ }^{+}$. In general, the contribution of each source identified with PMF was not significantly different to others found in the past, except for biomass burning during the episode in May, 2019, which was explained with the receptor model and meteorological parameters. Finally, this work should encourage the development of further studies in this geographic area, carrying out more extensive analyses of $\mathrm{PM}_{2.5}$.

\section{ACKNOWLEDGMENTS}

The authors acknowledge the technical assistance of M.I. Agapito-Abraham, M.I. Saavedra, M.C.
Torres-Barrera, and A.L. Alarcón. Also, the support of Dr. T. Castro, Dr. O. Peralta, Dr. M. Grutter, Dr. A. Jazcilevich, Dr. C. Solís, and Dr. R. Sosa is appreciated. This work was supported in part by DGAPAUNAM, under grants IN-102615 and IN-101719, as well as CONACyT 253051. AEHL, LVMP, SRC and JAMF acknowledge the support of CONACyT through scholarships. The Red Universitaria de Observatorios Atmosféricos de la Universidad Nacional Autónoma de México provided open access to its meteorological data. Additionally, the use of imagery from the NASA FIRMS application (http://firms. modaps.eosdis.nasa.gov/) operated by the NASA/ Goddard Space Flight Center Earth Science Data and Information System (ESDIS) project is recognized.

\section{REFERENCES}

Aiken A.C., Salcedo D., Cubison M.J. Huffman, J.A., DeCarlo P.F., Ulbrich I.M., Docherty K.S., Sueper D., Kimmel J.R., Worsnop D.R., Trimborn A., Northway M., Stone E.A., Schauer J.J., Volkamer R.M., Fortner E., de Foy B., Wang. J., Laskin A., Shutthanandan V., Zheng J., Zhang R., Gaffney J., Marley N.A., ParedesMiranda G., Arnott W.P., Molina L.T., Sosa G. and Jiménez J.L. (2009). Mexico City aerosol analysis during MILAGRO using high resolution aerosol mass spectrometry at the urban supersite (T0) - Part 1: Fine particle composition and organic source apportionment, Atmos. Chem. Phys. 9, 6633-6653. https://doi. org/10.5194/acp-9-6633-2009

Aldape F., Díaz R.V. and Hernández-Méndez B. (1999). PIXE analysis of airborne particulate matter from Xalostoc, Mexico: winter to summer comparison. Nucl. Instrum. Meth. B 150 (1-4), 445-449. https:// doi.org/10.1016/S0168-583X(98)00904-5

Aldape F. and Flores M.J. (2004). Source apportionment of fine airborne particulate matter collected in the Mexico City metropolitan area. Int. J. PIXE 14 (3-4), 147-160. https://doi.org/10.1142/S0129083504000215

Amador-Muñoz O., Villalobos-Pietrini R., Miranda J. and Vera-Ávila L.E. (2011). Organic compounds of $\mathrm{PM}_{2.5}$ in Mexico Valley: Spatial and temporal patterns, behavior and sources. Sci. Total Environ. 409 (8), 14531465. https://doi.org/10.1016/j.scitotenv.2010.11.026

Atanacio A.J. and Cohen D.D. (2016). The IAEA/RCA Fine and Coarse PMF Receptor Fingerprint Database (ANSTO/E 783). Lucas Heights, NSW: Australian Nuclear Science and Technology Organisation. Kirrawee, Australia, 48 pp.

Atkinson R.W., Kang S., Anderson H.R., Mills I.C. and Walton H.A. (2014). Epidemiological time series studies 
of $\mathrm{PM}_{2.5}$ and daily mortality and hospital admissions: a systematic review and meta-analysis. Thorax 69 (7), 660-665. doi: 10.1136/thoraxjnl-2013-204492

Barfoot K.M., Vargas-Aburto C., MacArthur J.D., Jáidar A. and García-Santibáñez F. (1984). Multi-elemental measurements of air particulate pollution at a site in Mexico City. Atmos. Environ. 18 (2), 467-471. https:// doi.org/10.1016/0004-6981(84)90124-0

Barrera V.A., Miranda J., Espinosa A.A., Meinguer J., Martínez J.N., Cerón E., Morales J.R., Miranda P.A. and Días J.F. (2012). Contribution of soil, Sulfate, and Biomass burning sources to the elemental composition of $\mathrm{PM}_{10}$ from Mexico City. Int. J. Environ. Res. 6 (3), 597-612. http://doi.org/ 10.22059/ijer.2012.530

Birch M.E. and Cary R.A. (1996). Elemental carbon-based method for monitoring occupational exposures to particulate diesel exhaust. Aerosol Sci. Tech. 25 (3), 221-241. http://doi.org/10.1080/02786829608965393

Borja-Aburto V.H., Castillejos M., Gold D.R., Bierzwinski S. and Loomis D. (1998). Mortality and ambient fine particles in southwest Mexico City, 1993-1995. Environ. Health Persp. 106 (12), 849-855. https://doi. org/10.1289/ehp.106-1533229

Calderón-Garcidueñas L., Kulesza R.J., Doty R.L., D'Angiulli A. and Torres-Jardón R. (2015). Megacities air pollution problems: Mexico City Metropolitan Area critical issues on the central nervous system pediatric impact. Environ. Res. 137 (2), 157-169. https://doi. org/10.1016/j.envres.2014.12.012

Carabalí G., Ríos B., Florean-Cruz L., Estévez H., ValdésBarrón M., Bonifaz R. and Riveros-Rosas D. (2019). Aerosol Optical Characteristics During the Biomass Burning Season in Southeastern Mexico. Water Air Soil Pol. 230 (10), 241. https://doi.org/10.1007/ s11270-019-4284-9

Choi J., Oh J.Y., Lee Y.S., Min K.H., Hur G.Y., Lee S.Y. and Shim J.J. (2018). Harmful impact of air pollution on severe acute exacerbation of chronic obstructive pulmonary disease: particulate matter is hazardous. Int. J. Chronic Obstr. 13 (1), 1053-1059. https://doi. org/10.2147/COPD.S156617

Chow J.C., Watson J.G., Edgerton S.A. and Vega E. (2002). Chemical composition of $\mathrm{PM}_{2.5}$ and $\mathrm{PM}_{10}$ in Mexico City during winter 1997. Sci. Total Environ. 287 (3), 177-201 https//doi.org/10.1016/S00489697(01)00982-2

Díaz R.V., López-Monroy J., Miranda J. and Espinosa A.A. (2014). PIXE and XRF analysis of atmospheric aerosols from a site in the West area of Mexico City. Nucl. Instrum. Meth. B 318 (1), 135-138. http://dx.doi. org/10.1016/j.nimb.2013.05.095

Edgerton S.A., Bian X., Doran J.C., Fast J.D., Hubbe J.M., Malone E.L., Shaw W.J., Whiteman C.D., Zhong
S., Arriaga J.L., Ortíz E., Ruíz M., Sosa G., Vega E., Limón T., Archuleta J., Bossert J.E., Elliot S.M., Lee J.T., McNair L.A., Chow J.C., Watson W.G., Coulter R.L., Doskey P.V., Gaffney J.S., Marley N.A., Neff W. and Petty R. (1999). Particulate air pollution in Mexico City: A collaborative research project. J. Air Waste Manage. 49 (10), 1221-1229. https://doi.org/1 $0.1080 / 10473289.1999 .10463915$

EPA (2014). Positive Matrix Factorization (PMF) 5.0 Model. Environmental Protection Agency [online]. https://www.epa.gov/air-research/positive-matrixfactorization-model-environmental-data-analyses $14 / 12 / 2019$

Espinosa A. A., Miranda J. and Pineda, J.C. (2010). Evaluation of uncertainty in correlated quantities: application to elemental analysis of atmospheric aerosols. Rev. Mex. Fís. E 56, 134-140.

Espinosa A.A., Reyes-Herrera J., Miranda J., Mercado F., Veytia M. A., Cuautle M. and Cruz J.I. (2012). Development of an X-ray fluorescence spectrometer for environmental science applications. Instr. Sci. Tech. 40 (6), 603-617. https://doi.org/10.1080/10739 149.2012.693560

Espinosa A.A., Miranda J., Hernández E., Reyes J., Alarcón A.L., Torres M.C. and Sosa R. (2019). Temporal variation of suspended particles (TSP, PM 10 , and $\mathrm{PM}_{2.5}$ ) and chemical composition of $\mathrm{PM}_{10}$ in a site at the coast of the Gulf of Mexico. Air Qual. Atmos. Hlth. 12 (11), 1267-1277. https://doi.org/10.1007/ s11869-019-00730-8

Garza-Galindo R., Morton-Bermea O., HernándezÁlvarez E., Ordoñez-Godínez S.L., Amador-Muñoz O., Beramendi-Orosco L., Retama A., Miranda J. and Rosas-Pérez I. (2019). Spatial and temporal distribution of metals in $\mathrm{PM}_{2.5}$ during 2013: assessment of wind patterns to the impacts of geogenic and anthropogenic sources. Environ. Monit. Assess. 191 (3), 165. https:// doi.org/10.1007/s10661-019-7251-4

Garza-Galindo R., Morton-Bermea O., HernándezÁlvarez E., Ordoñez-Godínez S.L., Amador-Muñoz O., Beramendi-Orosco L., Retama A., Miranda J. and Rosas-Pérez I. (2020). Platinum concentration in $\mathrm{PM}_{2.5}$ in the Mexico City Metropolitan Area: relationship to meteorological conditions. Hum. Ecol. Risk Assess. 26 (5), 1164-1174. https://doi.org/10.1080/ 10807039.2018.1542292

Gray H.A., Cass G.R., Huntzicker J.J., Heyerdahl E.K. and Rau J.A. (1986). Characteristics of atmospheric organic and elemental carbon particle concentrations in Los Angeles. Environ. Sci. Technol. 20 (6), 580-589 https//doi.org/10.1021/es00148a006

Gutiérrez-Ávila I., Rojas-Bracho L., Riojas-Rodríguez H., Kloog I., Just A. and Rothenberg S. (2018). 
Cardiovascular and cerebrovascular mortality associated with acute exposure to $\mathrm{PM}_{2.5}$ in Mexico City. Stroke 49 (7), 1734-1736. https://doi.org/10.1161/ strokeaha.118.021034

Guzmán-Torres D., Eiguren-Fernández A., CiceroFernández P., Maubert-Franco M., Retama-Hernández A., Villegas R.R. and Miguel A.H. (2009). Effects of meteorology on diurnal and nocturnal levels of priority polycyclic aromatic hydrocarbons and elemental and organic carbon in $\mathrm{PM}_{10}$ at a source and a receptor area in Mexico City. Atmos. Environ. 43 (17), 2693-2699. https://doi.org/10.1016/j.atmosenv.2009.03.003

Hernández-López A.E., Miranda J. and Pineda J.C. (2016). X-Ray Fluorescence Analysis of Fine Atmospheric Aerosols from a Site in Mexico City. J. Nucl. Phys. Mat. Sci. Rad. Appl. 4 (1), 25-30. https://doi. org/10.15415/jnp.2016.41003

Hernández-López A.E., Miranda J., Pineda J.C. and Reynoso-Cruces S. (2018). Analysis with X-ray Fluorescence of atmospheric aerosol simples collected south of Mexico City. Proceedings. XVI International Seminar on X-ray Analysis. Universidad de la Frontera, Chile. 4 to 7 november, 2018. https://sarx-jfmf-2018. ufro.cl/wp-content/uploads/Resumen-SARX JFMF2018.pdf

Hinojosa-Baliño I., Infante-Vázquez O. and Vallejo M. (2019). Distribution of $\mathrm{PM}_{2.5}$ Air Pollution in Mexico City: Spatial Analysis with Land-Use Regression Model. Appl. Sci. 9 (14) 2936. https://doi.org/10.3390/ app9142936

IAEA (2007). Quantitative X Ray Analysis System, Computer Manual Series No. 21. International Atomic Energy Agency. Vienna, Austria, 138 pp.

Ibinarriaga-Montiel P., Escamilla-Nuñez C., AlvaradoCruz I., Barraza-Villarreal A. and Romieu I. (2019). $\mathrm{PM}_{2.5}$ exposure and oxidative stress in a cohort of obese with and without asthma. Environmental Epidemiology 3,159 .

INEGI (2019). Parque vehicular. Instituto Nacional de Estadística, Geografía e Informática [online]. https:// www.inegi.org.mx/temas/vehiculos 10/08/20

JCGM (2008). Evaluation of measurement data-Guide to the expression of uncertainty in measurement. Joint Committee for Guides in Metrology. Int. Organ. Stand. Geneva. Switzerland, 134 pp.

Johnson K.S., de Foy B., Zuberi B., Molina L. T., Molina M.J., Xie Y., Laskin, A. and Shutthanandan V. (2006). Aerosol composition and source apportionment in the Mexico City Metropolitan Area with PIXE/PESA/ STIM and multivariate analysis. Atmos. Chem. Phys. 6, 4591-4600. https://doi.org/10.5194/acp-6-4591-2006

Justice C.O., Giglio L., Korontzy S. and Owen J. (2002). The MODIS fire products. Remote Sens. Environ.
83 (2), 244-262. https://doi.org/10.1016/S00344257(02)00076-7

Kadachi A.N. and Al-Eshaikh M.A. (2012). Limits of detection in XRF spectroscopy. X-Ray Spectrom. 41 (5), 350-354. https://doi.org/10.1002/xrs.2412

Kadowaki S. (1990). Characterization of carbonaceous aerosols in the Nagoya urban area 1. Elemental and organic carbon concentrations and the origin of organic aerosols. Environ. Sci. Technol. 24 (5), 741-744. https// doi.org/10.1021/es00075a020

Kreyszig E. (1970) Introductory Mathematical Statistics. John Wiley. New York, 470 pp.

Landsberger S. and Creatchman M. (Eds.). (1999). Elemental Analysis of airborne particles. Gordon and Breach. Amsterdam, Netherlands, 323 pp.

Lawson D.R. and Winchester J.W. (1967). A standard crustal aerosol as a reference for elemental enrichment factors. Atmos. Environ. 13 (7), 925-930. https//doi. org/10.1016/0004-6981(79)90003-9

Lumen (2018). Abundance of elements in the Earth crust. [online]. https://courses.lumenlearning.com/geology/ chapter/reading-abundance-of-elements-in-earthscrust $01 / 21 / 2020$

Maenhaut W. and Cafmeyer J. (1987). Particle induced $\mathrm{X}$-ray emission analysis and multivariate techniques: an application to the study of the sources of respirable atmospheric particles in Gent, Belgium. J. Trace Microprobe T. 5 (2-3), 135-158.

Maenhaut W. (2004). PIXE analysis of aluminum in fine atmospheric aerosol particles collected on Nuclepore polycarbonate filter. In: Quantifying uncertainty in nuclear analytical measurements. International Atomic Energy Agency, Vienna, Austria, pp. 63-76.

Martínez T., Lartigue J., López C., Beltrán C., Navarrete M., Cabrera L. and Riveroll M. (2000). INAA of aerosol samples in Mexico City. J. Radioanal. Nucl. Ch. 244 (1), 127-131. https://doi. org/10.1023/A:1006776501483

Martínez T., Lartigue J., Ávila-Pérez P., Carapio-Morales L., Zarazúa G., Navarrete M., Tejeda S. and Cabrera L. (2008). Characterization of particulate matter from the Metropolitan Zone of the Valley of Mexico by scanning electron microscopy and energy dispersive X-ray analysis. J. Radioanal. Nucl. Ch. 276 (3), 799-806. https://doi.org/10.1007/s10967-008-0635-5

Mejía-Ponce L.V., Hernández-López A.E., Reynoso-Cruces S., Pineda J.C., Mendoza-Flores J.A. and Miranda, J. (2018). Improvements to the $\mathrm{X}$-ray Spectrometer at the Aerosol Laboratory, Instituto de Física, UNAM. J. Nucl. Phys. Mat. Sci. Rad. Appl. 6 (1), 57-60. https:// doi.org/10.15415/jnp.2018.61009

Mejía Ponce L.V. (2020). Determinación de la concentración elemental de $\mathrm{PM}_{10}$ en un sitio del suroeste de 
la ZMVM, con una resolución temporal mejor que $24 \mathrm{~h}$, y desarrollo de modelos de receptor mediante Factorización de Matriz Positiva (PMF). Master of Sciences thesis, Posgrado en Ciencias de la Tierra, Universidad Nacional Autónoma de México. Mexico City, Mexico, 104 pp.

Méndez-García C.G., Romero-Guzmán E.T., HernándezMendoza H., Solís-Rosales C. and Chávez-Lomelí E.R. (2017). Assessment of the concentrations of $U$ and $T h$ in $\mathrm{PM}_{2.5}$ from Mexico City and their potential human health risk. J. Radioanal. Nucl. Ch. 314 (3), 1767-1775. https://doi.org/10.1007/s10967-017-5549-7

Miller J. and Miller, J.C. (2018). Statistics and chemometrics for analytical chemistry., $7^{\text {th }}$ ed. Pearson Education, Edinburgh, Scotland, 268 pp.

Miranda J., Morales J.R., Cahill T.A., Aldape F. and Flores M. (1992). A study of elemental contents in atmospheric aerosols in Mexico City. Atmósfera 5 (2), 95-108.

Miranda J., Cahill T.A., Morales J.R., Aldape F., Flores M.J. and Díaz R.V. (1994). Determination of elemental concentrations in atmospheric aerosols in Mexico City using proton induced X-ray emission, proton elastic scattering, and laser absorption. Atmos. Environ. 28 (14), 2299-2306. https://doi.org/10.1016/13522310(94)90483-9

Miranda J., Andrade E., Lopez-Suarez A., Ledesma R., Cahill T.A. and Wakabayashi P.H. (1996). A receptor model for atmospheric aerosols from a southwestern site in Mexico City. Atmos. Environ. 30 (20), 34713479. https://doi.org/10.1016/1352-2310(95)00477-7

Miranda J., López-Suárez A., Paredes-Gutiérrez R., González S., De Lucio O.G., Andrade, E., Morales J.R. and Ávila-Sobarzo M.J. (1998). A study of atmospheric aerosols from five sites in Mexico City using PIXE. Nucl. Instrum. Meth. B 136-138 (1), 970-974. https:// doi.org/10.1016/S0168-583X(97)00752-0

Miranda J., Crespo I. and Morales M.A. (2000). Absolute principal component analysis of atmospheric aerosols in Mexico City. Environ. Sci. Pollut. R. 7 (1), 14-18. https://doi.org/10.1065/espr199910.006

Miranda J., Barrera V.A., Espinosa A.A., Galindo O.S., Núñez-Orosco A., Montesinos R. C., Leal-Castro A. and Meinguer J. (2004). PIXE analysis of atmospheric aerosols from three sites in Mexico City. Nucl. Instrum. Meth. B 219-220 (1), 157-160. https://doi. org/10.1016/j.nimb.2004.01.045

Miranda J., Barrera V.A., Espinosa A.A., Galindo O.S. and Meinguer J. (2005). PIXE analysis of atmospheric aerosols in Mexico City. X-Ray Spectrom. 34 (4), 315319. https://doi.org/10.1002/xrs.823

Molina L.T., Madronich S., Gaffney J.S., Apel E., Foy B.D., Fast J., Ferrare R., Herdon S., Jimenez J.L.,
Lamb B., Osornio-Vargas A.R., Rusell P., Shauer J.J., Stevens P.S., Volkamer R. and Zavala M. (2010). An overview of the MILAGRO 2006 Campaign: Mexico City emissions and their transport and transformation. Atmos. Chem. Phys. 10 (18), 8697-8760. https://doi. org/10.5194/acp-10-8697-2010

Moreno T., Querol X., Pey J., Minguillón M.C., Pérez N., Alastuey A., Bernabé R.M., Blanco S., Cárdenas B., Eichinger W., Salcido A. and Gibbons W. (2008). Spatial and temporal variations in inhalable $\mathrm{CuZnPb}$ aerosols within the Mexico City pollution plume. J. Environ. Monitor. 10 (3), 370-378. https://doi. org/10.1039/B716507B

Morton-Bermea O., Amador-Muñoz O., Martínez-Trejo L., Hernández-Álvarez E., Beramendi-Orosco L. and García-Arreola M.E. (2014). Platinum in $\mathrm{PM}_{2.5}$ of the metropolitan area of Mexico City. Environ. Geochem. Hlth. 36 (5), 987-994. https://doi.org/10.1007/s10653014-9613-8

Morton-Bermea O., Garza-Galindo R., HernándezÁlvarez E., Ordoñez-Godínez S.L., Amador-Muñoz O., Beramendi-Orosco L., Miranda J. and RosasPérez I. (2018a). Atmospheric $\mathrm{PM}_{2.5}$ mercury in the metropolitan area of Mexico City. B. Environ. Contam. Tox. 100 (4), 588-592. https://doi.org/10.1007/ s00128-018-2288-6

Morton-Bermea O., Garza-Galindo R., Hernández-Álvarez E., Amador-Muñoz O., Garcia-Arreola M.E., OrdoñezGodínez S.L., Beramendi-Orozco L., Santos-Medina G.L., Miranda J. and Rosas-Pérez I. (2018b). Recognition of the importance of geogenic sources in the content of metals in $\mathrm{PM}_{2.5}$ collected in the Mexico City Metropolitan Area. Environ. Monit. Assess. 190 (2), 83. https://doi.org/10.1007/s10661-017-6443-z

Moya M., Castro T., Zepeda M. and Baez A. (2003). Characterization of size-differentiated inorganic composition of aerosols in Mexico City. Atmos. Environ. 37 (25), 3581-3591. https://doi.org/10.1016/S13522310(03)00345-5

Mugica V., Ortiz E., Molina L., De Vizcaya-Ruiz A., Nebot A., Quintana R., Aguilar J. and Alcántara E. (2009) PM Composition and Source Reconciliation in Mexico City, Atmos. Environ. 43 (32), 5068-5074. https://doi. org/10.1016/j.atmosenv.2009.06.051

Osornio-Vargas A.R., Bonner J.C., Alfaro-Moreno E., Martinez L., Garcia-Cuéllar C., Ponce-de-LeónRosales S., Miranda J. and Rosas-Pérez I. (2003). Proinflammatory and cytotoxic effects of Mexico City air pollution particulate matter in vitro are dependent on particle size and composition. Environ. Hlth. Persp. 111 (10), 1289-1293. https://doi.org/10.1289/ehp.5913

Paatero P. and Tapper, U. (1994). Positive Matrix Factorization - a Nonnegative Factor Model with Optimal 
Utilization of Error-Estimates of Data Values. Environmetrics, 5 (1), 111-126. https://doi.org/10.1002/ env. 3170050203

Paredes-Gutiérrez R., López-Suárez A., Miranda J., Andrade E. and González J.A. (1997). Comparative study of elemental contents in atmospheric aerosols from three sites in Mexico City using PIXE. Rev. Int. Contam. Ambie. 13 (2), 81-85.

Peralta O., Adams D., Castro T., Grutter M. and Varela A. (2016). Mexico's University Network of Atmospheric Observatories. Eos, 97 (4), 8-10. https://doi. org/10.1029/2016EO045273

Peralta O., Ortínez-Alvarez A., Basaldud R., Santiago N., Álvarez-Ospina H., de la Cruz, K., Barrera V., Espinosa M.L., Saavedra I., Castro T., Martínez-Arroyo A., Páramo V.H., Ruíz-Suárez L.G., Vázquez-Galvez F.A. and Gavilán A. (2019). Atmospheric black carbon concentrations in Mexico. Atmos. Res. 230, 104626. https://doi.org/10.1016/j.atmosres.2019.104626

Querol X., Pey J., Minguillón M.C., Pérez N., Alastuey A., Viana M., Moreno T., Bernabé R.M., Blanco S., Cárdenas B., Vega E., Sosa G., Escalona S., Ruíz H. and Artiñano B. (2008). PM speciation and sources in Mexico during the MILAGRO-2006 Campaign, Atmos. Chem. Phys. 8, 111-128. https://doi.org/10.5194/ acp-8-111-2008

Quintana R., Serrano J., Gómez V., de Foy B., Miranda J., Garcia-Cuellar C., Vega E., Vázquez-López I., Molina L. T., Manzano-León N., Rosas-Pérez I. and Osornio-Vargas A.R. (2011). The oxidative potential and biological effects induced by $\mathrm{PM}_{10}$ obtained in Mexico City and at a receptor site during the MILAGRO Campaign. Environ Pollut. 159 (12), 3446-3454. https://doi.org/10.1016/j.envpol.2011.08.022

Raga G.B., Baumgardner D., Castro T., Martínez-Arroyo A. and Navarro-González R. (2001). Mexico City air quality: a qualitative review of gas and aerosol measurements (1960-2000). Atmos. Environ. 35 (23), 4041-4058. https://doi.org/10.1016/S13522310(01)00157-1

Ramírez O., de la Campa A.S., Amato F., Catacolí R.A., Rojas N.Y. and de la Rosa J. (2018). Chemical composition and source apportionment of $\mathrm{PM}_{10}$ at an urban background site in a high-altitude Latin American megacity (Bogotá, Colombia). Environ. Pollut. 233 (1), 142-155. https//doi.org/10.1016/j.envpol.2017.10.045.

Reynoso Cruces S. (2020) Muestreo y análisis elemental del aerosol atmosférico presente en un ambiente de trabajo. Bachelor thesis, Facultad de Ciencias, Universidad Nacional Autónoma de México. Mexico City, Mexico, 92 pp.

Rodríguez-Espinosa P.F., Flores-Rangel R.M., MugicaÁlvarez V. and Morales-García S.S. (2017). Sources of trace metals in $\mathrm{PM}_{10}$ from a petrochemical industrial complex in Northern Mexico. Air Qual. Atmos. Hlth. 10 (1):69-84. https//doi.org/10.1007/s11869-0160409-0

Salcedo D., Alvarez-Ospina H., Peralta O. and Castro T. (2018) $\mathrm{PM}_{1}$ Chemical Characterization during the ACU15 Campaign, South of Mexico City. Atmosphere 9 (6): 232. https://doi.org/10.3390/atmos9060232

Saldarriaga-Noreña H., Hernández-Mena L., SánchezSalinas E., Ramos-Quintana F., Ortíz-Hernández L., Morales-Cueto, Alarcón-González V. and RamírezJiménez S. (2014). Ionic Composition in Aqueous Extracts from $\mathrm{PM}_{2.5}$ in Ambient Air at the City of Cuernavaca, Mexico. J. Environ. Prot. 5 (13), 13051315. https//doi.org/10.4236/jep.2014.513124

Saloman E.B., Hubbell J.H. and Scofield J.H. (1988). $\mathrm{X}$-ray attenuation cross sections for energies $100 \mathrm{eV}$ to $100 \mathrm{keV}$ and elements $Z=1$ to $Z=92$. Atom. Data Nucl. Data 38 (1), 1-197. https://doi.org/10.1016/0092640X(88)90044-7

Santibáñez-Andrade M., Chirino Y.I., González-Ramírez I., Sánchez-Pérez Y. and García-Cuéllar C.M. (2020). Deciphering the Code between Air Pollution and Disease: The Effect of Particulate Matter on Cancer Hallmarks. Int. J. Mol. Sci. 21 (1), 136-150. https:// doi.org/10.3390/ijms21010136

Saxena, P. and Seigneur C. (1987). On the oxidation of $\mathrm{SO}_{2}$ to sulfate in atmospheric aerosols. Atmos. Environ. 21 (4), 807-812. https://doi.org/10.1016/00046981(87)90077-1

SEDEMA (2010). Inventario de Emisiones de la Zona Metropolitana del Valle de México 2008, Contaminantes Criterio. Secretaría de Medio Ambiente. Mexico City, Mexico, $100 \mathrm{pp}$.

SEDEMA (2016). Calidad del aire en la Ciudad de México. Informe anual 2015. Secretaría de Medio Ambiente, Mexico City, Mexico, 175 pp.

SEDEMA (2017). Calidad del aire en la Ciudad de México. Informe 2016. Secretaría de Medio Ambiente, Mexico City, Mexico, 168 pp.

SEDEMA (2018). Inventario de Emisiones de la Ciudad de México, contaminantes criterio, tóxicos y compuestos de efecto invernadero. Secretaría de Medio Ambiente. Mexico City, Mexico, 215 pp.

SEDEMA (2019). Programa para contingencias ambientales atmosféricas en la ZMVM. Secretaría de Medio Ambiente [online] http://www.aire.cdmx.gob.mx/descargas/ultima-hora/calidad-aire/pcaa/pcaa-historicocontingencias.pdf 10/01/20

SEDEMA (2020a). Bases de datos de la Red Automática de Monitoreo Atmosférico (RAMA). Secretaría de Medio Ambiente [online] http://www.aire.cdmx.gob. $\mathrm{mx} /$ default.php?opc $=\% 27 \mathrm{aKBh} \% 27$ 01/20/2020 
SEDEMA (2020b) Bases de datos de la Red Manual de Monitoreo Atmosférico (RAMA). Secretaría de Medio Ambiente [online] http://www.aire.cdmx.gob.mx/ default.php?opc $=\% 27 \mathrm{aKBhnmE}=\% 27 \& \mathrm{r}=\mathrm{b} 3 \mathrm{BlbmR}$ hdGEvcmVkX21hbnVhbC9yZWRfbWFudWFsX3B sb21vLmNzdg==07/01/2020

Sosa-Echeverría R., Alarcón-Jimémez A.L., Torres-Barrera M.C., Jaimes-Palomera M., Retama-Hernández A., Sánchez-Álvarez P., Granados-Hernández E. and Bravo-Álvarez H. (2019). Spatial and temporal variation of acid rain in the Mexico City Metropolitan Zone. Atmósfera 32 (1), 55-69. http://dx.doi.org/10.20937/ atm.2019.32.01.05

SSA (1993). Mexican Official Standard NOM-026SSA1-1993, Environmental health. Criterion to evaluate air quality with regard to lead $(\mathrm{Pb})$. Standard value for lead $(\mathrm{Pb})$ concentration. Mexico City: Secretaría de Salud. Diario Oficial de la Federación. 23 de diciembre de 1994.

SSA (2014). Mexican Official Standard NOM-025SSA1-2014, Environmental health. Permissible limits for $\mathrm{PM}_{10}$ and $\mathrm{PM}_{2.5}$ suspended particles concentrations in air and evaluation criteria. Mexico City: Secretaría de Salud. Diario Oficial de la Federación. 20 de agosto de 2014

Téllez-Rojo M.M., Rothenberg S.J., Texcalac-Sangrador J.L., Just A.C., Kloog I., Rojas-Saunero L.P., GutiérrezÁvila I., Bautista-Arredondo L.F., Tamayo-Ortiz M., Romero M., Hurtado-Díaz M., Schwartz J.D., Wright R. and Riojas-Rodríguez H. (2020). Children's acute respiratory symptoms associated with $\mathrm{PM}_{2.5}$ estimates in two sequential representative surveys from the Mexico City Metropolitan Area. Environ. Res. 180, 108868. https://doi.org/10.1016/j.envres.2019.108868

Taylor J.R. (1997). An Introduction to Error Analysis. $2^{\text {nd }}$ ed. University Science Books. Sausalito, California, United States, $327 \mathrm{pp}$.

Thurston G.D. and Spengler J.D. (1985). A quantitative assessment of source contributions to inhalable particulate matter pollution in metropolitan Boston. Atmos. Environ. 19 (1), 9-25. https://doi.org/10.1016/00046981(85)90132-5

Turpin B.J. and Huntzicker J.J. (1995). Identification of secondary organic aerosol episodes and quantitation of primary and secondary organic aerosol concentrations during SCAQS. Atmos. Environ. 29 (23), 3527-3544. https//doi.org/10.1016/1352-2310(94)00276-Q

UNAM (2019) Portal de Estadística Universitaria. Universidad Nacional Autónoma de México [online] http:// www.estadistica.unam.mx 12/17/2019

UNO (2018). World Urbanization Prospects: The 2018 Revision. United Nations. Department of Economic and Social Affairs, Population Division [online] http:// WUP2018-F11a-30_Largest_Cities.xls 12/17/2019

Vega E., García I., Apam D., Ruíz M.E. and Barbiaux, M. (1997). Application of a chemical mass balance receptor model to respirable particulate matter in Mexico City. J. Air Waste Manage. 47 (3), 524-529. https://doi. org/10.1080/10473289.1997.10464452

Vega E., Reyes E., Ruiz H., García J., Sánchez G., Martínez-Villa G., González U., Chow J. and Watson J.G. (2004). Analysis of $\mathrm{PM}_{2.5}$ and $\mathrm{PM}_{10}$ in the atmosphere of Mexico City during 2000-2002. J. Air Waste Manage. 54 (7), 786-798. https://doi.org/10.1080/104732 89.2004.10470952

Vega E., Eidels S., Ruiz H., López-Veneroni D., Sosa G., González E., Gasca J., Mora V., Reyes E., Sánchez-Reyna G., Villaseñor R., Chow J., Watson J.G. and Edgerton S.A. (2010). Particulate Air Pollution in Mexico City: A Detailed View. Aerosol Air Qual. Res. 10 (3), 193-211. https://doi.org/10.4209/ aaqr.2009.06.0042

Vega E., Ruiz H., Escalona S., Cervantes A., López-Veneroni D., González-Avalos E. and Sánchez-Reyna G. (2011). Chemical composition of fine particles in Mexico City during 2003-2004. Atmos. Pollut. Res. 2 (4), 477-483. https://doi.org/10.5094/APR.2011.054

Watson J.G., Robinson N.F., Chow J.C., Henry R.C., Kim B.M., Pace T.G., Meyer E.L. and Nguyen Q. (1990). The U.S. EPA/ DRI Chemical Mass Balance Receptor Model, CMB 7.0. Environ. Modell. Softw. 5 (1), 38-49

WHO (2005). WHO Air quality guidelines for particulate matter, ozone, nitrogen dioxide and sulfur dioxide. World Health Organization. Geneva, Switzerland, $22 \mathrm{pp}$.

Ye J., Abbatt J.P. and Chan A.W. (2018). Novel pathway of $\mathrm{SO}_{2}$ oxidation in the atmosphere: reactions with monoterpene ozonolysis intermediates and secondary organic aerosol. Atmos. Chem. Phys. 18 (8) 5549-5565. https://doi.org/10.5194/acp-18-5549-2018 


\section{SUPPLEMENTARY MATERIAL}

\section{S1. XRF ACCURACY VERIFICATION}

Accuracy verifications of XRF elemental analyses have been carried out using the NIST standard reference material 2783, Air Particulate on Filter Media (Mejía-Ponce et al. 2018). The ratio of elemental concentrations measured with XRF to the certified values are displayed in figure S1. Moreover, a statistical $t$-test was applied to compare the measured with certified values by means of the Stata ${ }^{\circledR}$ package (Stata, 2018), although the test overlooks the uncertainties in the certified and in the measured concentrations. Figure S1 considers these uncertainties. Consequently, in the graph the ratios in green do not present significant differences with the certified values $(p<$ $10 \%$ ), while ratios in blue are significantly higher $(\mathrm{Mn})$ and those shown in red are significantly lower (Mg, Al, Si, and Zn). However, Si has only reference and no certified values. In summary, the discrepancies are acceptable. There is good agreement between both values for most elements, when the uncertainties and the $t$-test are considered. Therefore, the XRF results of concentration determinations in the $\mathrm{PM}_{2.5}$ elemental analyses can be considered as reliable, with care for $\mathrm{Mg}, \mathrm{Al}, \mathrm{Mn}$, and $\mathrm{Zn}$.

\section{S2. XRF LIMITS OF DETECTION}

Limits of detection (LOD) for a Teflon ${ }^{\circledR}$ filter loaded with $\mathbf{P M}_{2.5}$ are displayed in figure $\mathbf{S 2}$, determined under the same X-ray fluorescence experimental conditions as the reference material; thus, it is expected to have similar detection limits for the targets.

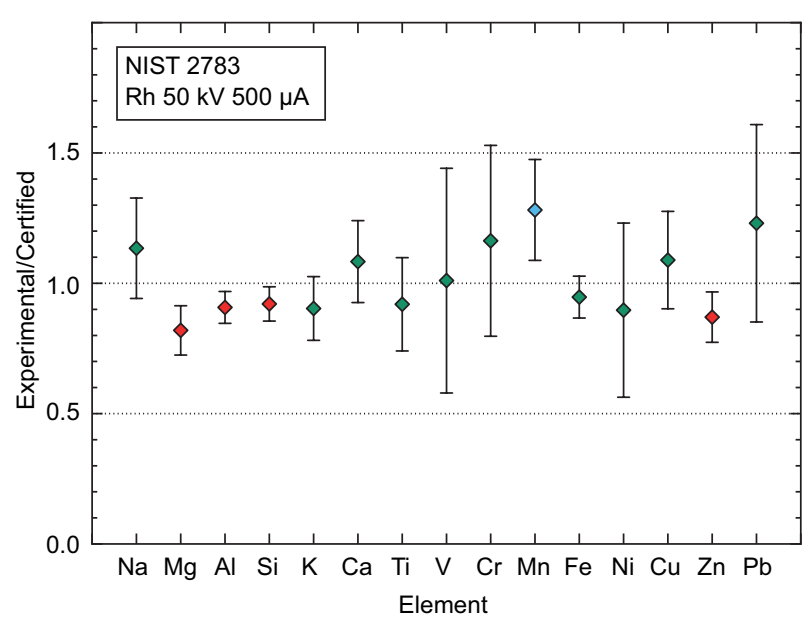

Fig. S1. Ratios of elemental concentrations measured with XRF to certified concentrations in the NIST 2783 standard reference material.
These LOD are calculated on the basis of background radiation, and is proportional to the square root of the number of counts in the background below the analyzed X-ray peak (Kadachi and Al-Eshaikh 2012). This number is given in the report of the analysis of each spectrum with QXAS (IAEA 2007).

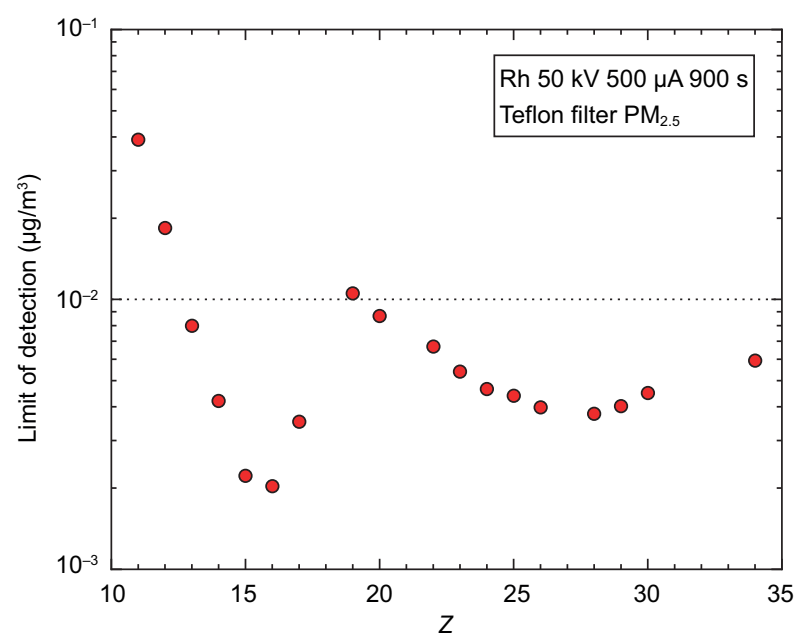

Fig. S2. Limits of detection for elements with atomic number $Z$ between 11 and 34, for a Teflon ${ }^{\circledR}$ filter loaded with $\mathrm{PM}_{2.5}$, under the experimental conditions described in the text.

\section{S3. RECOVERY TESTS FOR ION CHROMA- TOGRAPHY ANALYSIS}

Instrumental calibration curves for all species were constructed in a range between $0.1 \mathrm{mg} / \mathrm{L}$ and $10 \mathrm{mg} / \mathrm{L}$. Also, recovery tests for ion analysis were carried out using the NIST SRM-2786, reference material classified as fine atmospheric particle matter. Approximately $15 \mathrm{mg}$ of SRM was placed on a PTFE membrane filter (diameter $25 \mathrm{~mm}, 3 \mu \mathrm{m}$ pore size) (Pall, NY, USA). Since the certificate sheet for SRM does not contain information on ammonium ion, the SRM in the filter was spiked with $20 \mu \mathrm{L}$ of a solution of high purity ammonium sulfate (Sigma Aldrich, MO, USA) at a concentration of $50 \mathrm{mg} / \mathrm{L}$. Afterwards, in order to simulate the retention of the $\mathrm{PM}$ in the filter when using a low volume sampler, the filter was placed in a holder, inside a desiccator chamber, as shown in figure $\mathbf{S 3}$. The holder was connected to a vacuum pump (Cole Parmer, IL, USA) and the flow rate was kept at $5 \mathrm{~L} / \mathrm{min}$ for 10 min. Finally, the filter was left in the desiccator for $24 \mathrm{~h}$ before the extraction. The tests were performed by triplicate. The extraction and analysis procedure were the same as the PM samples. Calibration and recovery results are shown in table S-I. 


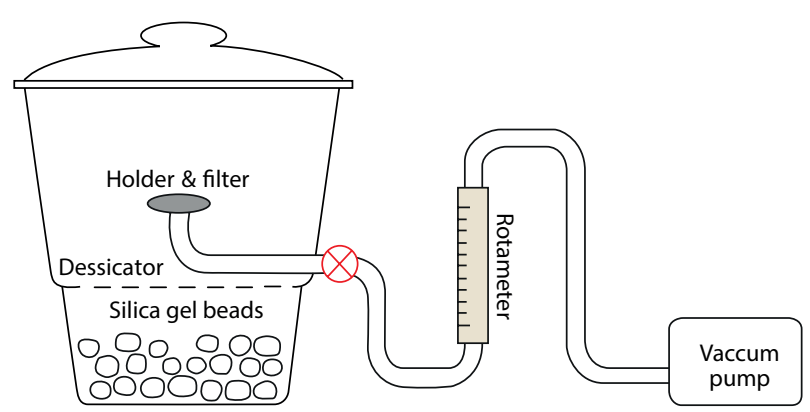

Fig. S3. Diagram of the device built for recovery tests for ion chromatography analysis.

TABLE S-I. PEARSON CORRELATION COEFFICIENTS FOR INSTRUMENTAL ANALYTICAL METHOD $\left(r_{\mathrm{I}}\right)$. PRECISION IS INDICATED AS RELATIVE STANDARD DEVIATION FOR ANALYTICAL METHOD (RSD, \%). LIMITS OF DETECTION (LOD) FOR THE INSTRUMENTAL ANALYSES ARE INDICATED IN mg/L. RECOVERY YIELD EXPRESSED AS PERCENTAGE FOR ANALYTES PRESENT IN FINE ATMOSPHERIC PARTICLE MATTER, SRM-2786 EXTRACTED BY ULTRASOUND ASSISTED EXTRACTION AND ANALYZED BY IONIC CHROMATOGRAPHY.

\begin{tabular}{lcccc}
\hline Analyte & $r_{\mathrm{I}}{ }^{\text {a }}$ & RSD & LOD & Recovery \\
\hline $\mathrm{Ca}^{2+}$ & 0.9996 & 1.36 & 2.50 & $79(10)$ \\
$\mathrm{Na}^{+}$ & 0.9995 & 2.42 & 1.74 & $85(8)$ \\
$\mathrm{Cl}^{+}$ & 0.9999 & 1.35 & 2.26 & $42(15)$ \\
$\mathrm{NH}_{4}{ }^{+}$ & 0.9999 & 0.81 & 2.22 & $82(6)$ \\
$\mathrm{SO}_{4}{ }^{2-}$ & 0.9999 & 1.22 & 2.29 & $90(7)$ \\
$\mathrm{NO}_{3}{ }^{-}$ & 0.9994 & 2.62 & 1.77 & N.D. \\
$\mathrm{K}^{+}$ & 0.9998 & 1.64 & 1.79 & N.D. \\
$\mathrm{Mg}^{2+}$ & 0.9991 & 2.89 & 3.29 & N.D. \\
\hline
\end{tabular}

a. $r_{\mathrm{I}}$, RSD and IDL were calculated with seven calibration levels, except $\mathrm{Ca}^{2+}, \mathrm{Mg}^{2+}$ and $\mathrm{NO}_{3}{ }^{-}$, calculated with five calibration levels.

${ }^{b}$ N.D. Not determined, because the analyte is not reported in the SRM-2786 certificate sheet.

\section{S4. DEDUCTION OF THE EXISTENCE OF A LOCAL Pb SOURCE}

The concentrations of $\mathrm{Pb}$ are notably larger than in the past, pointing out to a situation that requires immediate attention; possible explanations are either a local source or a contribution of biomass burning, as obtained with the PMF analysis below. The association of $\mathrm{Pb}$ with this source has been confirmed previously (Atanacio and Cohen 2016). The accuracy of the XRF measurements was discussed above (Fig. S1). In particular, there is a good agreement between the $\mathrm{Pb}$ concentration measured with XRF and the certified value of the 2783 SRM, demonstrating that this observation is not an analytical artifact. This is also supported by figure $\mathbf{S} 4$, where the region around the $\mathrm{Pb} \mathrm{L} \mathrm{a}_{\mathrm{a}}$ peak in an exposed filter is compared to a blank Teflon ${ }^{\circledR}$ filter; the presence of the $\mathrm{Pb}$ signal is apparent. Additionally, the only reference to $\mathrm{Pb}$ concentrations near the sampling site is obtained from the closest station of the manual network (Pedregal), but refers to total suspended particulate (TSP) (SEDEMA $2020 \mathrm{~b}$ ). The mean value for the sampling period in 2016 is $0.0070 \pm 0.0068 \mu \mathrm{g} / \mathrm{m}^{3}$, which is much lower than the value reported in this work for the same year.

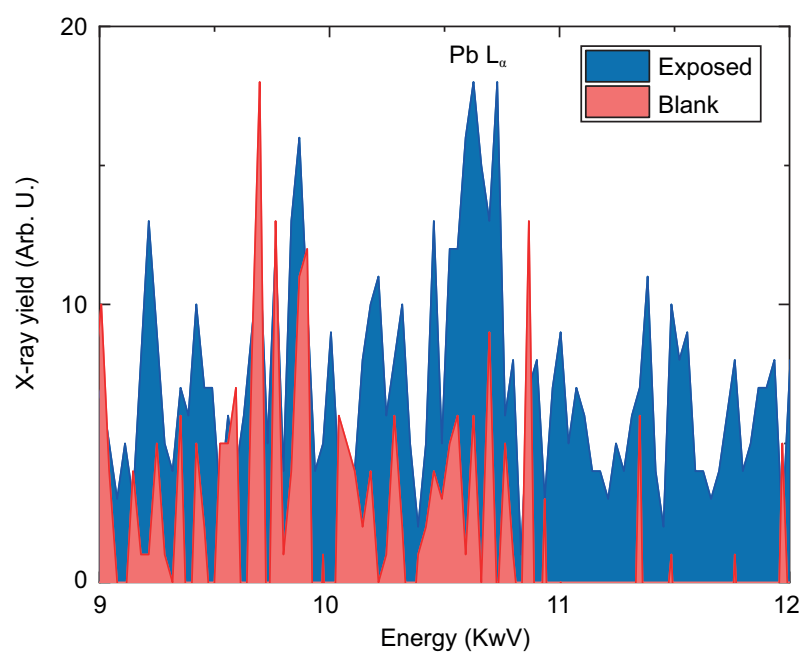

Fig. S4. Region of XRF spectra around the $\mathrm{Pb} \mathrm{L}_{\mathrm{a}}$ line, corresponding to exposed and blank Teflon ${ }^{\circledR}$ filters. 